
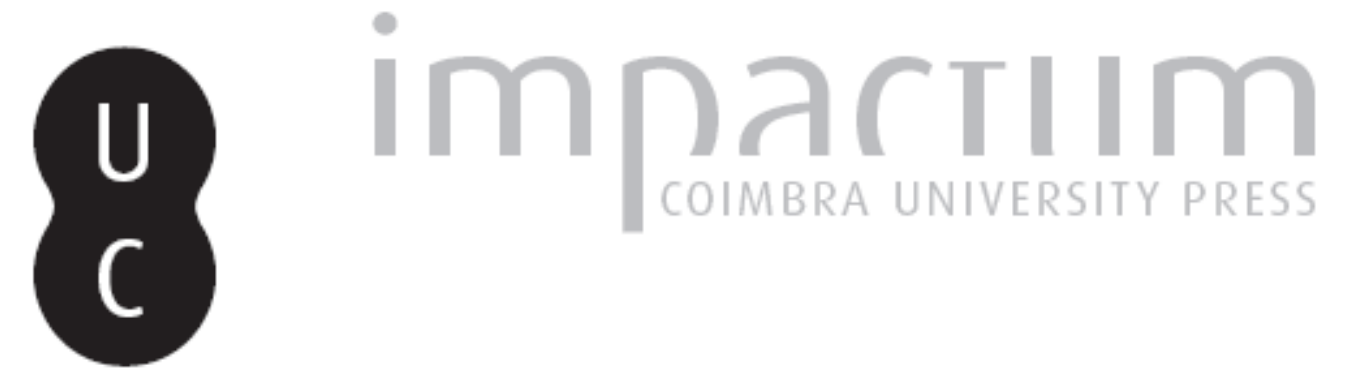

\title{
Notícias arqueológicas de Braga em jornais bracarenses
}

Autor(es): $\quad$ Oliveira, Eduardo Pires de

Publicado por: Imprensa da Universidade de Coimbra

URL persistente:

URI:http://hdl.handle.net/10316.2/45652

DOI:

DOI:https://dx.doi.org/10.14195/1647-8657_24_1

Accessed : $\quad$ 26-Apr-2023 07:16:22

A navegação consulta e descarregamento dos títulos inseridos nas Bibliotecas Digitais UC Digitalis, UC Pombalina e UC Impactum, pressupõem a aceitação plena e sem reservas dos Termos e Condições de Uso destas Bibliotecas Digitais, disponíveis em https://digitalis.uc.pt/pt-pt/termos.

Conforme exposto nos referidos Termos e Condições de Uso, o descarregamento de títulos de acesso restrito requer uma licença válida de autorização devendo o utilizador aceder ao(s) documento(s) a partir de um endereço de IP da instituição detentora da supramencionada licença.

Ao utilizador é apenas permitido o descarregamento para uso pessoal, pelo que o emprego do(s) título(s) descarregado(s) para outro fim, designadamente comercial, carece de autorização do respetivo autor ou editor da obra.

Na medida em que todas as obras da UC Digitalis se encontram protegidas pelo Código do Direito de Autor e Direitos Conexos e demais legislação aplicável, toda a cópia, parcial ou total, deste documento, nos casos em que é legalmente admitida, deverá conter ou fazer-se acompanhar por este aviso.

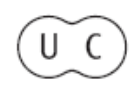


FACULDADE DE LETRAS

INSTITUTO DE ARQUEOLOGIA

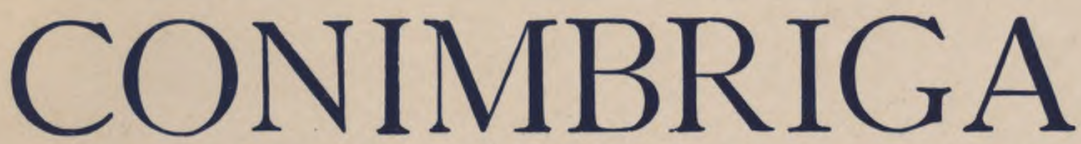

VOLUMEXXIV

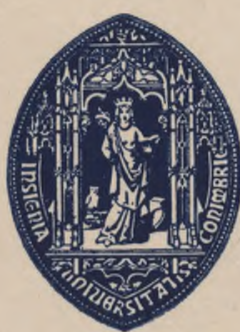

UNIVERSIDADE DE COIMBRA

1985 
Técnico da Unidade de Arqueologia da Universidade do Minho

\section{NOTICIAS ARQUEOLÓGICAS DE BRAGA EM JORNAIS BRACARENSES}

«Conimbriga», XXIX (1985), p. 5-83

Resumo: Transcrevem-se, anotando-as, notícias de interesse arqueológico relativas ao concelho de Braga, publicadas em jornais bracarenses desde a 2. ${ }^{a}$ metade do séc. xix até aos começos do séc. xx. A análise desse noticiário permite precisar o contexto arqueológico de muitos achados.

RÉSUMÉ: Des notices archéologiques sur Braga et son terme publiées dans les journaux depuis la deuxième moitié du XIX ${ }^{\text {ème }}$ siècle jusqu'au début du XX $\mathrm{X}^{\text {ème }}$ sont ici transcrites por l'Auteur. L'analyse de ces informations permet de préciser le contexte de beaucoup de trouvailles archéologiques. 
(Página deixada propositadamente em branco) 


\title{
NOTÍCIAS ARQUEOLÓGICAS DE BRAGA EM JORNAIS BRACARENSES
}

\author{
(Estudos Bracarenses, 9)
}

1. Os jornais donde extraímos as notícias que agora apresentamos são todos de Braga. Na medida do possível, vimos as colecções completas; no entanto, e dado que dificilmente poderemos, em tempos próximos, ter possibilidades de tempo para vermos outras colecções, incluímos aqui algumas notícias de outros jornais bracarenses de que só compulsámos um ou outro número.

As colecções consultadas foram:

O Bracarense: 1855 a 1859

Comércio do Minho: 1872 a 1921 (pesquisa integral)

Correio do Minho: 1926 a 1974

Diário do Minho: 1919 a 1974

Ecos do Minho: 1911 a 1918 (pesquisa integral)

O Imparcial: 1912 a 1915 (pesquisa integral)

$O$ Independente: 1858 a 1859

A Propaganda: 1910 (pesquisa integral)

Consultámos ainda números avulsos de outros jornais, como O Brado Liberal, A Abelha, Notícias do Norte, O Amigo do Povo, $O$ Liberal, Liberdade, etc..

2. Esta pesquisa foi efectuada porque, no decorrer dos estudos que vimos fazendo sobre a arqueologia da cidade e do concelho de Braga, temos deparado com informações que nos pareciam estar incorrectas. O recurso à «notícia do dia» veio-nos confirmar a cautela que é preciso tomar com os relatos feitos fora do tempo (quantas vezes só muitos anos depois ou, pior ainda, por 
interposta pessoa): veja-se o caso flagrante da noticia número 92 , que dá como local de achado ocasional de uma inscrição, a rúa Cruz de Pedra, o que contraria a informação dada 21 anos mais tarde por CoRTez, 1958, que a dizia procedente da Fonte do Idolo, quer dizer, do extremo oposto da cidade romana e de um contexto muito peculiar, erro que só agora é desfeito.

De salientar ainda é o facto de muitas destas notícias estarem hoje inteiramente perdidas, não se conhecendo delas qualquer informação; são mais alguns locais que assim ficam referenciados. E, mais uma vez, a chamada de atenção para a necessidade de se fazerem pesquisas sistemáticas na tão rica fonte de informação que são os jornais.

3. O critério que usamos foi o de transcrever todas as notícias que parecessem ter um mínimo de interesse para a Epigrafia, Numismática, História da Arqueologia, Carta Arqueológica, etc., fazendo apenas uma enumeração comentada, no fim, de outras que nada pudessem trazer, agora, de novo: visitas de estudo, cursos de divulgação, textos de simples divulgação, textos já publicados em outros locais, anterior ou posteriormente, etc..

Sempre que possível, acrescentamos algumas notas para uma melhor referência da notícia. As notas, para facilitar, terão a mesma numeração das notícias.

Excluímos os textos do Cónego Arlindo Ribeiro da Cunha e de Alberto Feio porque temos em vista a sua publicação: em separado, no caso do primeiro destes nomes; e no contexto da sua obra dispersa, no caso do segundo. 


\section{Sepultura antiga}

Descobriu-se uma sepultura antiga, no dia 30 de Junho, proxima da capella da Senhora-a-Branca, do lado do norte, por occasião de se andar a fazer um passeio diante d'uma casa particular.

Já por vezes, segundo é publico, tem sido descobertas mais algumas sepulturas antigas nas mesmas visinhanças da capella, tanto do lado do norte como do lado do sul.

A construcção geral destas sepulturas, é de tijolos assentes em barro por camadas alternadas, sem primor de construcção. E os tijolos ainda mesmo também não manifestam esmero de fabrico.

A sepultura antiga que acaba agora de ser descoberta, era d'uma analoga construção das de mais outras por vezes descobertas, mas forrada no seu interior de «calcáreo (lioz) de grosseiro polido», no fundo, nos lados, e nos topos.

O lavrado do calcáreo não era regular senão apenas pelas faces interiores: nas faces externas havia ainda bem sensiveis indicios da falta de aprimoramento.

A tampa da sepultura era tosca e grosseira, e composta de pedras transversaes. Apenas pela face inferior é que ellas manifestavam indicios d'algum lavrado. Eram de «arkosa», frequente por estas pedreiras d'aqui.

Os lados e os topos do «calcáreo» apenas estavam juxta postos aos tijolos do sepulchro, estando os lados mantidos no seu competente desvio por duas «varas de ferro», sobre as quaes assentavam as pedras da tampa.

Appareceu dentro uma ossada de homem, a qual dava indicios de haver pertencido a «pessoa bem fornida, e de estatura apessoada». E tudo leva a crer que era de pessoa de consideração na ordem social da sua epocha d'enterramento.

De que edade, porem, seria acaso a sepultura descoberta? Seria do tempo dos romanos?

De certo que não: fallece-lhe a construcção propria d'essa epocha provecta. Nem os tijolos revelam o fabrico de então, nem o seu organisamento é o proprio d'esses tempos do povo rei, (populum late regem). Nem o estado da conservação dos ossos revela tão remota edade.

Qual será, pois, a antiguidade provável de essa sepultura, os tijolos e ferro da qual, com a sua respectiva ossada, se acham guardados na casa da camara desta cidade?

E' o que procuraremos fazer nos seguintes numeros.

O Bracarense, 10-7-1857

Conimbriga, 24 (1985), 5-83 


\section{Chegada}

O snr. Augusto Soromenho acha-se outra vez entre nós, continuando a assistir no Hotel Real.

O ilustre commissionado, da nossa academia, vem ultimar os seus trabalhos sobre as lapidas antigas da cidade.

O sr. Augusto Soromenho tenciona dirigir-se ao depois, d'aqui para as Caldas de Vizella, a íim de examinar as lapidas romanas d'aquella localidade

O Independente, 4-11-1858

\section{Antiguidades}

$\mathrm{Na}$ excongosta da Palmatoria, hoje tapada, existiam no muro das freirás dos Remedios, umas pedras antigas, que eram do tempo dos romanos, e do dominio da vista do publico e dos amadores.

Não queremos dizer com isto que fosse boa ou má medida o contracto com que se procedeu á tapagem da congosta. O que porem, é de necessidade e de brio nacional, é que se extraham do muro as pedras, e que se colloquem n'um sitio publico, onde todos as possam ver.

Hão de concordar, que isto não é desarrasoado, e lembrávamos mesmo, o local das Carvalheiras como um digno depositario d'aquellas antiguidades, que ennobrecem a Braga.

Gazeta de Braga, 8-8-1865

\section{Sepultura}

Nas excavações que se andam fazendo na rua de Traz da Sé para o encanamento das aguas, appareceu uma sepultura, que se estende por debaixo da torre. Não tem inscripção alguma pela qual se possa precisar o tempo a que remonta. Os ossos estão reduzidos a pó, e o maior pedaço que se vê nem tem o comprimento d'um decimetro.

Comércio do Minho, 22-7-1873

\section{Columna romana}

Nas escavações a que se está procedendo para a construcção da nova rua da Sé, appareceu, nas proximidades da torre denominada da Ajuda, que ha annos se demoliu, uma columna, cuja inscripção, não obstante estar algo carcomida, mostra ser dos marcos miliarios da via-romana. 
6. Duas lapidas romanas

No anno anterior - 1874 - procurou o sr. visconde de Pindella ao professor Pereira Caldas, com uma carta d'um amigo de Lisboa pedindo-lhe a verificação de duas fotografias em que se figuravam duas lápidas romanas de Braga.

O professor Pereira-Caldas respondeu ao sr. visconde de Pindella, na tarde do mesmo dia, enviando-lhe a noticia que passamos a tianscrever das Artes e Lettras de Lisboa - publicação periodica esplendida, honrosa para o nosso paiz.

\title{
II
}

Tiramos do $n .^{\circ} 9$ da $3 .^{\text {a }}$ serie esta transcripção, precedida pelo exm. ${ }^{\circ}$ Vilhena Barbosa - illustração provadissima — das seguintes palavras lisongeiras:

...«Publica este numero duas lápidas romanas com inscripções, existentes na cidade de Braga, cuja descripção e decifração - — como abaixo segue — devernos á benevolencia do sr. Pereira-Caldas, digno professor do lyceu d'aquella cidade, e distincto archéologo».

III.

- «As copias das duas lápidas romanas estão exactas no seu aspecto geral, conforme ellas o revelam no muro onde estão collocadas - muro outr'ora da extincta cangosta da Palmatoria, e hoje de quintal particular na travessa do Hospital de S. Marcos.

- «Examinadas com miudeza, e mais com auxilio do tacto que por meio da vista, não é difícil ao epigraphista o poder lêr as lacunas dos desenhos e bastantes que são.

IV.

— «Eis a incripção da lápida dos libertos — Agathópodo e Zetho:

\author{
AGATHOPOD (o) \\ T(iti). SATRI (liberto) \\ Z B T H V S \\ CONSERWS
}

— «Ambos os libertos são gregos d'origem, como os seus nomes patenteam. — Não são unicos aqui. 
V.

- «No cimo da lápida está figurada em relêvo, ainda que um pouco apagada, urna pátera de pequenissimo cabo, se nao é por ventura um píleo de pequenissima acuminação. - As fasces, a seguite, e o málleo, figurados por baixo da inscrição, não deixam de confirmar a supposição da pátera — a phiállé dos gregos.

- «No fundo da lápida lê-se a custo um pouco:

Foi achada

a 14 palmos

neste sitio

anno 1751

VI.

- «A leitura Titi Satri Liberto, attenta a palavra Conservus, parece-me preferivel á de Titi Satri Filio, usual aliás n'outras inscripções, frequentes entre nós aqui em Braga.

VII

—'«Eis a inscripção da lápida do soldado romano bèjense, achada ao pé da anterior:

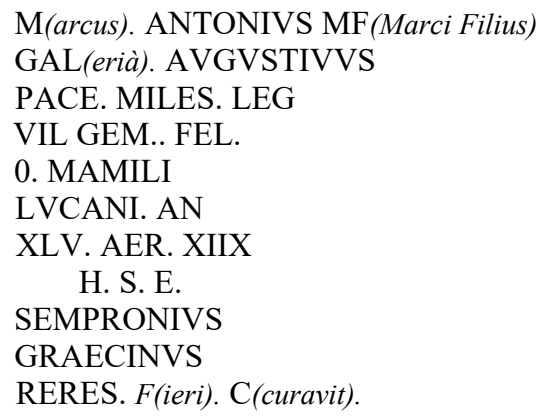

VIII.

(O M e F estão ambos ligados, assim como o I e V do Augustinus, sendo mais alto o I: e o VII tem um traço por cima).

IX

- «Ha uma cousa a notar n'esta inscripção de Marco Antonio Agostinho, da tribu Galéria, oriundo de Beja (Pax Julia), e soldado da legião septima gémina feliz. 
- E' que a palavra AER não diz respeito a era alguma; dizendo-o designadamente ao estipendio militar AES.

— «Com esta observação — óbvia para o epihraphista, mas extranha talvez ao amador curioso — não há difficuldades de leitura n'esta inscripção.

$\mathrm{X}$.

— «Escrevi em lettras minúsculas, como é d'uso epigráphico, o complemento das palavras da inscripção abbreviadas, em que o amador curioso poderia achar difficuldades de leitura.

— «para os epigraphistas, era isso desnecessário.

— «Braga, 1874.

-- «PEREIRA--CALDAS.

XI.

A estas linhas que deixamos transcriptas, apenas acrescentaremos agora, que o quintal onde existem estas duas lápidas, pertence ao sr. José Antonio Rebello da Silva, abastado proprietario bracarense.

Estão alli collocadas no muro da cêrca do convento de Religiosas dos Remedios, da Terceira Ordem do Seraphico Padre S. Francisco d'Assis casa que têm a regalia, na occasião do fallecimento dos prelados primazes, de tanger os sinos a sé vacante, como costumam fazer os conegos na egreja cathedral.

XII.

Muito seria para desejar, que o nosso senado municipal fizesse transferir d'alli estas duas lápidas, collocando-as ambas no campo das Carvalheiras.

Ficavam então conjunctas com as columnas milliarias das vias romanas de Braga a Astorga, e com outras lápidas ainda do povo dominador do mundo - com rasão cognominado na phrase do poeta Mantuano como rei à larga, assimilando-a do seu emphático laté regem.

\section{XIII.}

São ambas estimáveis estas duas lápidas romanas, sendo-o com primazia a do soldado bèjense.

E' um documento inconcusso de granito, comprovativo do engano do consciencioso Masdeu - auctor da Historia Critica de la Espana, y de la cultura española en todo genero, traduzida do italiano em hispanhol - em querer achar á força n'estas Ipáidas, como outros epigraphistas portuguezes e hispanhoes, alguma era no estipendio d'ellas.

Conimbriga, 24 (1985), 5-83 


\section{XIV.}

Deixaram os bracarenses perder outr'ora urna lápida d'um soldado romano, que era tribuno da segunda cohorte de vigiles, e de que só resta a memoria em Grutero — na sua valiosa colecção epigráphica.

Acharão os amadores em 1101, 3, esta memoria de Lucio Terendo, da tribu Quirina.

\section{XV.}

Não deixemos perder agora tambem esta lápida prestimosa.

E' uma congénere valiosa das nossas tres lápidas de Caio Julio Vero Maximino - urna quasi gasta de todo - comprovativas de seu quinto podér tribunicio, contra o asserto geral dos historiadores da sua epocha imperatoria.

E' congénere valiosa egualmente da nossa lápida de Flavio Magnencio, comprovativa de terem as Hispanhas seguido o seu partido como as Gallias - quando elle se rebellára entre os narbonenses contra Constante, filho de Constantino Magno, fazendo-se acclamar imperador pelas suas legiões.

XVI.

Salvemol-a d'alguma eventualidade que a possa destruir: - e colloquemol-a onde aos amadores seja fácil aprecial-a á vontade, no meio das suas outras congéneres.

PEREIRA-CALdas

Brado Liberal, 30-4-1875

7. Carta do professor Pereira-Caldas do Lyceu Nacional Bracárense ao Illustradissimo Arcebispo Coadjutor de Braga e Futuro Sucessor o Ex. ${ }^{\circ}$ D. João Chrysostomo d'Amorim Pessoa para Inauguração d'um Atheneu Archeologico em Braga.

Ex. ${ }^{\text {mo }}$ Sr..

Entre os Prelados enobrecedores d'esta Egreja Primaz de Braga, foi D. Diogo de Sousa o maior dos beneficiadores d'esta capital do Minho. Sabe-o V. E muito bem, como consummado na historia do nosso paiz. - Não é por isso como novidade, que lembro agora a V. E. esta circumstancia.

Ampliou e reformou D. Diogo de Sousa esta cidade, restaurando-a e additando-a com mão dadivosa, condigna d'um dos successores de S. Geraldo - o amigo dilecto do conde D. Henrique, progenitor egregio do Primeiro dos nossos reis.

Conimbriga, 24 (1985), 5-83 
Melhorou D. Diogo de Sousa ruas e praças antigas; abriu ruas e praças novas; aformoseou edifícios acanhados, erigiu edifícios desafogados: construiu fonte publicas; agremiou em um grande hospital os pequenos d'então; engrandeceu templos antigos; levantou templos novos; e estabeleceu estudos publicos geraes.

No meio d'estes engrandecimentos successivos de Braga, não se esqueceu D. Diogo de Sousa de velar ainda pela conservação das reliquias archeologicas da dominação romana, esparsas na sua diocese em estado de se perderem d'um dia em outro.

«Mandou levantar em muito boa ordem - Diz na Historia dos Arcebispos de Braga o nosso D. Rodrigo da Cunha - as pedras e columnas que os romanos, quando senhorearam Braga, levantaram a diversos imperadores: - para que n'aquellas lettras tivessem os curiosos em que gastar o tempo, e se fizessem peritos nas antiguidades da sua patria».

Preferi transcrever este contexto - em logar de o exprimir com frases minhas - do Tomo II. Cap. LXXI n. 2 da obra alludida. - Dou assim toda a venerabilidade a esta occorrencia momentosa.

Desde esses tempos de D. Diogo de Sousa atégora — vai em mais de 3 séculos e meio - tem ido sempre em augmento o achado de monumentos romanos em Braga, acontecendo também por vezes a perda d'alguns d'elles no meio da propria abundancia. - Tem tido assim logar mais uma vez - em desproveito do estudo e com magua dos estudiosos - aquelle inopem me copia fecit vulgarissimo.

A inauguração d'um Atheneu Archeologico n'esta cidade de Braga, com protecção do Prelado da Diocese e do Governador-Civil do Districto, é o meio profícuo do meu ideal d'ha muito, para aqui se desenvolver á larga - como convém a esta capital do Minho - a concepção archeologica de D. Diogo de Sousa. - Fallecia-me no entanto a opportunidade auspiciosa para isto; e deparou-se-me agora.

Nasceu V. E. com espirito civilisador e coração patriota, como comprovam á saciedade os actos de V. E. na vastissima Egreja Primaz do Oriente, onde será indelevel o renome de V. E....

No pouco tempo em que temos a V. E. aqui em Braga - gerindo a administração d'esta diocese vastissima - tem V. E. lançado os liceamentos d'um governo auspiciosissimo. - Nos desenvolvimentos successivos d'elle, a que V. E. mira com energia inabalavel, hade o proceder illustrado de V. E. grangear o renome dos Diogos de Sousa, dos Bartholomeus dos Martyres, dos Agostinhos de Jesus, dos Rodrigos da Cunha, dos Rodrigos de Moura Telles, e dos Caetanos Brandões.

Em nome d'estas virtudes civilisadoras e patrioticas de V. E. - em recordação dos tempos saudosos do nosso tyrocinio universitario - digne-se V. E. assumir agora a iniciativa da realisação d'este meu alvitre d'ha muito.

Com ella prestará V. E. a esta cidade de Braga - a nossa patria adoptiva d'agora - os serviços vadosissimos de D. Fr. Manuel do Cenaculo ás cidades de Beja e Evora, onde será sempre inolvidável o renome d'este seu Prelado. 
O nosso Governador-Civil do districto- illustrado como é - folgará d'associar-se a V. E. n'esta iniciativa auspiciosa. - O nosso visconde de Margaride é amador das lettras.

Ao lado de personagens de tam elevada posição social, agremiar-se-hão dedicados os cultores conscienciosos dos nossos estudos archeologicos, concorrendo com os seus esforços patrioticos para esta instituição prestimosa.

Não será só de proveito para os curiosos seculares - como poderia talvez antolhar-se á primeira vista — a inauguração do Atheneu Archeologico de Braga.

Com esta instituição auspiciosa, será fácil até ao clero da nossa diocese - frequentador d'esta capital do Minho em seu tyrocínio escholar - o locupletar-se de conhecimentos indispensáveis das antiguidades patrias.

«Como os emprêgos a que os ecclesiasticos são chamados, têm diversos caracteres - devendo por isso no clero, tomado em sua generalidade brilhar o merecimento de todos os generos d'erudição — é necessário promover e sustentar este decoro da Egreja».

Disse-o assim o nosso egregio D. Fr. Manuel do Cenaculo - em nome da rasão - na sua Instruç̧ão Pastoral do Bispo de Beja ao Clero e Ordenandos da sua Diocese, dada á luz em Lisboa em 1784.

Para um Prelado da illustração vastissima de V. E., não ha novidade alguma n'este asserto: - mas ha da minha parte n'esta occasião, como prezador do renome dos nossos varões preclaros, a obrigação litteraria de não olvidar a um dos maiores.

Ninguem conhecia melhor que elle, o que póde e o que vale o clero cultivado.

Não foi com effeito ao brandir das armas, que a heresia pelagiana fugira vencida n'outrora: - foi ao esplendor dos conhecimentos profícuos do clero, versado em todo o genero d'erudição.

No desmoronamento do mundo romano - ante as hordas immensas dos barbaros — não houve legiões algumas, que lhes fizessem rosto então. - Arrojou-se no entanto a contel-as nos excessos — com as armas unicas da palavra - o clero cultivador das lettras.

Foi assim, que S. Serverino domára a Odoacro. - Foi assim, que S. Leão detivera a Atila. - Foi assim, que S. Gregorio amansára os lombardos.

Quando a noite da barbárie cobrira de todo a terra com as trevas da ignorancia; foi no clero dos mosteiros, onde então se asylára vivida a erudição geral. - Sem estas «arcas de salvação litteraria», teria sido submergido no diluvio d'entáo o mundo do saber.

Para exemplicar - aos que o não sabem - o que é, o que vale o clero versado em todos os generos d'erudição, sobra-me o que fica summariado de D. Emilio Castelar - varão immensamente maior que o seu nome — nas suas famigeradíssimas Cartas a um Bispo.

O dia 24 de Junho - como dia do Sancto do nome de V. E. - parece-me o dia mais apropriado para a inauguração do Atheneu Archeologico de 
Braga. - A não ser esse no entanto o dia escolhido, ser-lhe-ha períerivel então dia de de S. Pedro e S. Paulo - Apostolos memorabilissimos da Egreja Cristan, de que Y. E. é apostolo tambem.

$$
\text { De V. E. }
$$

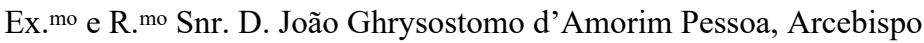
Coadjuctor de Braga e Futuro Successor

Respeitador Affectuoso

José Joaquim da Silva Pereira-Caldas, Professor do Lyceu no Curso de Mathematicas Elemenares no $4 .^{\circ}$ e $5 .^{\circ}$ anno, e no Curso de Lingua Alleman no $1 .^{\circ}$ e $2 .^{\circ}$ anno.

Braga, 1 de Junho de 1876.

Comércio do Minho, 17.6.1876

\section{A the neu archeologico}

Está marcado o dia 29 do corrente para a inaguração d'um Atheneu archeologico, que, por iniciativa do illustre professor do lyceu, dr. Pereira-Caldas, - um dos nossos antiquarios mais justamente considerados, tanto no reino como no estrangeiro - e com a valiosissima coadjuvação do preclarissimo prelado que actualmente preside aos destinos da Egreja bracarense, se vae estabelecer n'esta cidade.

A inaguração será feita n'um dos salões do palacio archiepiscopal, e presidida pelo exm. ${ }^{\circ}$ e revm. ${ }^{0}$ snr. arcebispo coadjutor.

Para este fim começaram a ser expedidas as cartas de convite, que são do theor seguinte:

Não desconhece V. ... a importancia e utilidade do estudo das antiguidades em geral, e com muita especialidade as da nossa patria memorável.

Até nos assumptos em apparencia triviaes, e a que nós com frequência não prestamos toda a attenção, vem dar-nos luz muitas vezes o estudo das antiguidades, para a intelligencia cabal d'elles.

Será bastante o descer apenas a um exemplo.

Não ha quem não conheça a expressão vulgar - levar as lampas a alguém - como significativa de levar-lhe vantagem, e de conseguir um desejo com antecipação.

Os que se acostam ao nosso Duarte Nunes de Leão, na sua Origem da Lingua Portugueza, olham a palavra lampas como substantivo oriundo do adjectivo lampo, significativo de temporão: e dão como exemplo comprovativo os fructos lampos, colhidos na quadra do S. João.

Eis-aqui as proprias palavras de Duarte-Nunes:

Conimbriga, 24 (1985), 5-83 
«E disemos lampeiro o que faz alguma cousa ante tempo, tomado das figueiras que dão figos temporãos. O que parece vem de lampas por relampado»».

Não se accommodam de certo com esta explicação, os que são dados ao estudo das antiguidades em geral. E' do certame das lampadas, jogo publico dos gregos, que deduzem a origem e explicação da phrase alludida.

Eis-aqui o que se lê a este respeito nas Annotações ao Tractado sobre a Unidade da Egreja, composto pelo Bispo de Carthago S. Cypriano, e traduzido do latim em portuguez pelo nosso Luiz Antonio d'Azevedo.

«Chamaram sempre os portuguezes lampeiro ao homem que diz, ou faz alguma cousa antes de tempo, derivando o vocabulo - a meu ver — da palavra grega lampadéforos, ou como nós dizemos lampadéforo, que significa o que leoa a lampada, tocha, ou brandão: — alludindo ao jogo dos gregos Lampadeforia ou Lampa dedrómia, isto é, certame de levar lampadas - de correr com lampadas, isto é, fachas accésas; cuja descripção achará o leitor na Grécia Feriada de Meursio no jogo Lampas».

«O que serve pois para o nosso intento, é saber, que n'aquelle certame só conseguia a victoria, e a quem se não apagava a facha na carreira em que ia, até o logar destinado. E porque ás vezes corriam mais de vagar, para que a agitação da carreira lhes não apagasse a facha - motivo por que davam palmadas uns nos outros para excitar o riso entre si e aos mais - declarando assim ao mesmo tempo, que o affrouxar na carreira não era o rigor da lei, ou estilo d'aquelle certame».

«D’aqui vem o ser provável, e eu para mim o tenho quasi por certo, que - assim como no referido certame naturalmente haviam muitos por brio d'estugar o passo, mais accelerados do que d'elles se requeria, vindo assim a perder a victoria; - do mesmo modo ao homem que se antecipa circumspecto no que obra, deram os portuguezes o nome de lampeiro, visto adiantar-se nas coisas mais do que a sua obrigação requer, e o decoro o permite; perdendo também - se é que o tinha - o conceito de discreto e sisudo».

«A mesma phrase portugueza - levar as lampas a alguém, por levar vantagem, é tirada immediatamente do certame que acima referimos, onde lampas é syncope de lampadas: - e esta mesma é a origem do termo lampso».

«A este jogo alludiram os auctores gregos e latinos, fallando dos ascendentes que entregam a seus descendentes bem como accesa a candea da vida, para se perpetuarem sobre a terra: - como se póde ver em Platão no Livro VI das Leis pag. 300 do vol. VIII da edição de Duas-Pontes; Lucrecio Livr. II. v. 78; Persio Sat. VI v. 61; e finalmente Varão De Re Rustica Livr. III. Cap. 16 onde Appio, tendo discorrido physicamente da natureza e economia das abelhas, materia que não era a principal de que alli se havia de tractar, mas só do fructo d'ellas, sobre o qual parece que esperava com impaciencia Axio que já se entrasse a fallar, e querendo dar logar a Merula para expor a utilidade e o fructo das mesmas abelhas, diz assim:

«Sed, o Merula, Axius noster ne, dum baec audit, physicam arcessat

- outros lêem addiscal, achiscal, ou accuset, que é o mesmo que arcessal

- quod de fructu nihil dixi, nunc cursu lampada tibitrado. 
«Vem a dizer: - - Mas para que o nosso amigo Axio, em quanto ouve estas cousas, não se impaciente com a physica - porque não tenho dicto nada do fructo das abelhas - agora, na mesma carreira que levava, te entrego a minha lampada nas tuas mãos, ó Merula, para dares principio ao teu discurso»».

Apesar do promettimento de se não descer senão apenas a um exemplo da importancia e utilidade do estudo das antiguidades; descer-se-ha, ainda assim, a um exemplo mais somente.

Far-se-ha com as proprias palavras do tradutor anonymo do Theologo e Orador. Christão, instruido sobre as regras d'entender e expor a Sagrada Escriptura, nos Quatro Livros da Doutrina Christan do inclito Doutor da Egreja Santo Agostinho.

Eis-aqui o contexto fiel do Padre Antonio Joaquim da Congregação do Oratorio de Lisboa, que fora o alludido traductor anonymo. Transcreve-se do Prologo do Tom. 1:

«Todo o catholico convêm, em que n'este logar de S. Mattheus, Cap. XVI, onde Christo Senhor Nosso diz a S. Pedro: - Tili daboclaves regni coelorum: et quod-cumque ligaveris super terram, erit ligatum et in coelis; et quodcumque salveris super terram, erit solulum et in coelis: - Eu te dou as chaves do reino do céo; tudo o que atares sobre a terra, será atado no ceo; e tudo o que desatares na terra, será desatado no ceo.

Todos convem, digo, em que n'este logar se falla do poder que o Senhor deu a seus ministros sobre as almas, as quaes podem em certo modo, por meio censuras e d'absolvição sacramental, atar e desatar. Esta a intelligencia, quanto á substancia; mas a propriedade com que o Senhor fallou, só se conhece entendida a razão, porque disse antes atares e desatares e não abrires e fechares; pois é certo, que com as chaves só se abre e fecha, e não se ata nem desata».

«O reconhecimento da propriedade d'esta expressão só se póde conseguir pelos monumentos antigos e historia profana».

«E' pois de saber, que algum dia não havia nas portas o que chamamos fechaduras; mas faziam as vezes d'essas uns nós de corda ou de couro mui artificiosos. Cada qual tinha o seu, com que resguardava a sua casa. $\mathrm{O}$ artifício estava, em terem as pontas de tal sorte escondidas, que se lhes não conhecia facilmente o princípio».

«D'aqui procedeu aquelle nó celebrado da antiguidade, que chamaram Gordiano ou Cordiano, de que faz menção Quinto Curcio no Livr. III: - Notabile erat vinculum adstrictum cimóluribus nodis in semetipsos implicatis, celantibus nexus - Onde refere Curcio o dicto d'Alexandre: - Nihil, iniquit, interest quo modo solvantur: - gladioque ruptis omnibus loris, oraculi sortem vel illusit, vel implevit».

«Estava este nó em um famoso templo da Asia, com um oraculo que dizia, que quem o destasse seria senhor da Asia».

«Nem todos os nós seriam tam artificiosos como este; mas todos tinham seu artificio maior ou menor: - e para os desatar, serviam ordinariamente chaves de pau, de figura mui differente das que hoje se usam; porque umas 
eram recurvadas como foices, outras constavam d'uma haste comprida com uma pequena curvatura no fim».

"Consta o que dizemos d'estas figuras de chaves, d'algumas estatuas antigas onde se vèem esculpidas, principalmente nas $d^{9}$ Osiris e Isis.

«Dos ?iós ,faz menção Homero na Odyssea, VIII. 443.

«Refere o poeta n'este logar os presentes, que os pheacianos mandaram a Ulysses em um cofre, recommendando-lhe que elle o fechasse com o seu nó, para que ninguem os roubasse: - e que Ulysses assim o fizera, com o nó engenhoso que Circe lhe ensinára».

«O mesmo se comprova d'Eustachio, pag. 1603, vers. 50

«Correndo os tempos, se mudou a fórma das chaves e das fechaduras em diversas figuras».

«Usou-se muito terem as portas um buraco, por onde se mettia a chave, e esta corria uma barra de ferro, que estava pela parte de dentro da porta. - D'este modo, deixava fechada a sua casa, quem sahia d'ella para fóra».

«Algumas d'estas chaves imitavam a figura d'uma Cruz.

«Supposto isto, clarissimo fica a propriedade com que Christo fallou na sobredicta metáphora, explicando-se por atar e desatar, e não d'outro modo».

Visto como os monumentos antigos explicam usos e costumes d'outr'ora, e que d'outro modo não seriam de nós conhecidos; corre-nos o dever de velar pela conservçaoão d'essas reliquias archeologicas, estudando-as minuciosamente á luz da philologia, em proveito da illustração da humanidade.

Foi esta a causal essencial da creação dos museus $d^{9}$ antiguidades, como foi a origem civilisadora das conferencias dos estudiosos do passado, explicando e illucidando cada um d'elles os espécimens de mais predilecção.

Eis-aqui o que se lê em relação á importancia e utilidade dos museus, no opusculo As Ruinas do Carmo, devido á penna do nosso escriptor Sá Villela de Lisboa:

«Os museus são hoje tidos - mais do que nunca - como um dos melhores e mais importantes recursos para o estudo das sciendas, das bellas-artes, e da industria».

"As nações mais civilisadas disvellam-se na propagação e no enriquecimento d'estes templos da illustração, que já se contam aos centos, e até mesmo pelas cidades de $2 .^{\mathrm{a}}$ e $3 .^{\mathrm{a}}$ ordem».

«Em 1868, contavam-se 43 museus municipaes ou departamentaes só em França: - e bem se entende, que n'este numero não são comprehendidos os primeiros museus d'aquelle ¿Ilustrado paiz».

«A capital do pequeno reino da Dinamarca contêm não menos de 8 museus: - e a collecção do seu museu $d^{9}$ anatomia é muito interessante para os estudos anthropologicos».

«Mas entre todos os museus, os que últimamente vão attrahindo mais a attenção, e as diligencias dos sabios de todos os paizes, são os museus archeologicos, especialmente os $d^{9}$ archeologia pre-historica».

«Citam-se já hoje museus archeologicos muito notáveis, e da maior importancia para a sciencia».

Conimbriga, 24 (1985), 5-83 
«Entre os menos conhecidos, podem citar-se como dos mais ricos e apreciáveis o museu archeologico de Gluny, o museu de Namur, o museu de Saint-Germain, verdadeiramente pre-historico, e o museu ethnographico de Copenhague, opulento de preciosidades orientaes, que náo occupam menos de 28 salas.

- Em Madrid, tambero já existe, ha muito, um museu $d^{*}$ archeologia: e a nossa visinha Hispanha pode datar, sobre 20 annos, algumas das suas curiosas pesquisações archeologicas pelas cavernas da Andaluzia, e d'outras provincias:

- apesar de que infelizmente esta nação, victima constante das commoções politicas, não tem podido desinvolver taes explorações, como os seus archeologos — já hoje conhecidos na Europa — muito desejariam».

«Entre nós - e muito me custa fazer esta confissão - ainda que nos estudos e investigações archeologicas se possam citar nomes illustres, desde André de Resende até ao zeloso Cenáculo; modernamente quasi que chegou a escarnecer-se d'esta scienda, desdenhando-se até das indagações litterarias sobre as nossas antiguidades».

N'estes ultimos tempos, despertou-se felizmente em nossa patria o amor dos estudos archeologicos, e expandiu-se no paiz com entusiasmo auspicioso, graças ao impulso vigoroso da alavanca da associação.

No anno de 1875, deram-se á luz em Lisboa umas Observações sobre o actual estado do ensino das artes em Portugal, a organisação dos museus, e o serviço dos monumentos historicos e da archeologia. - Offereceu-as à Commissão, nomeada por Decreto de 10 de Novembro de 1875, um vogal da mesma Commissão.

Eis-aqui o que se lê n'este opusculo ácerca da importancia e utlidade dos museus provincials:

«A creação em Lisboa de museus centraes não dispensa a existência de museus provinciaes, tanto mais que temos para elles elementos em muitas terras»».

Não é por certo necessario, que haja em cada capital de districto pequenas collecções, que sejam — por assim dizer — reproducções em eschala diminuta dos museus de Lisboa. - O que é necessario, é que - aproveitando os os nucleos ou elementos que existam em cada terra - se tracte com cuidado da sua conservação, e do seu engrandecimento».

«Os municipios poderiam facilmente ser levados a concorrer para a sustentação d'estes museus; e até os particulares não deixariam de contribuir, para que elles tomassem increemnto».

«Junto das collecções provinciaes, deve também haver pequenas bibliothecas, contendo livros de bellas-artes, d'archeologia, e sobretudo d'applicação do desenho à industria; e além d'isso, photographias de monumentos, d'objectos d'arte, etc. etc..

Como V. estará compenentrado da importancia e utilidade dos museus d'antiguidades; e de que são as associações dos amadores os sustentáculos essenciaes d'estas instituições prestimosas; não se negará de certo V. a comparecer n'estes Paços Archiepiscopaes no dia 29 do corrente, dadas que sejam as 11 horas da manhan. 
Terá então logar a inaguração solemne do Atheneu Archeologico de Braga, consagrado ao desempenho amplamente momentoso, de que ficam exemplificadas em summa as proficuidades inconcussas.

A comparencia de V. a esta solemnidade - no dia e hora que lhe são designados - abrilhantará o acto para que é merecidamente convidado, e que é continuação d'iniciativas gloriosas de Prelados Illustres, de que sempre terá d'ufanar-se esta Egreja Bracarense.

Braga, 15 de Junho de 1876.

De V.

Comércio do Minho, 22-6-1876

\section{Atheneu Archeologico}

Teve logar a inaguração do Atheneu Archeologico Bracarense no dia 29, commemorativo dos Apostolos S. Pedro e S. Paulo, no salão da galeria dos Prelados Primazes nos paços archiepiscopaes.

Presidiu o venerando Arcebispo, e foi numerosa e selecta a reunião allí congregada: compunha-se de quanto ha em Braga em illustração e amadores, e em cultores das bellas-artes. E' a primeira das reuniões n'esta especie, que tem tido logar n'esta capital do Minho, tanto em quantidade como em qualidade.

$\mathrm{O}$ venerando Arcebispo, ao approximar-se o meio-dia, appareceu em meio dos seus convidados, a quem saudou com a delicadeza e mimo em que timbra, e leu um brilhante Discurso em relação á utilidade e inauguração do instituto projectado, pedindo por fim a nomeação d'uma Mesa Provisoria.

O snr. Pereira-Caldas, iniciador da concepção, agradeceu ao venerando Prelado a voz eloquente e a mão poderosa, com que S. Ex. ${ }^{a}$ tomou a peito esta instituição; agradeceu igualmente a solicitude e dedicação dos cavalheiros presentes; e dirigiu-se depois aos representantes da imprensa da localidade e de fóra que no salão se achavam como convidados.

Dizendo, que não devia alçar a voz em presença do venerando Prelado, entregou ao director decano da imprensa local, o snr. José Maria Dias da Costa, director do "Commercio do Minho», uma Allocução impressa em cartão dourado, que no mesmo dia disse começar a mandar distribuir pelos cavalheiros reunidos, e de certo enviará também ao jornalismo do paiz. Logo depois, entregou outra Allocução igual ao decano dos correspondentes da imprensa de fóra da cidade, o snr. Antonio Maria da Fonseca, correspondente do «Commercio do Porto». Pediu a um e outro, que recebessem esta homenagem, como consideração ao modo como a imprensa do paiz tinha annunciado a sua concepção, realisada alli nobremente pelo venerando Arcebispo, a quem tinha em primeiro logar entregado duas Allocuções analogas, cada uma d'ellas douradas com todo o mimo, e em cartão de superior formato.

Publicaremos o Discurso do venerando Arcebispo, se no-lo permitir S. Ex. ${ }^{\text {a }}$, de quem nos honraremos de o solicitar.

A Allocução do snr. Pereira-Caldas aqui a publicamos agora: 


\section{ALLOCUÇÃO}

\section{SENHORES}

Vereis amor da patria não movido

De premio vil, mas alto e quasi eterno;

Que não é premio vil ser conhecido

Por um pregão do ninho meu paterno.

\section{Camões - LUSí ADAS}

Ao manusear pela primeira vez as Decadas da Asia do nosso João de Barros, calaram-me com magua no coração algumas palavras exprobatorias, irrogadas alli contra a nossa negligencia geral na coordenação de memorias historicas, enunciadoras dos nossos feitos assombrosos.

Eis-aqui estas palavras censuratorias, escriptas pela penna eloquente do nosso classico famigerado, filho talvez dos mais gloriosos de Braga, no meio da incerteza geral dos seus hiographos:

«Certo grave e piedosa cousa d'ouvir» - Vêr uma nação a que Deus deu tanto animo, que - se tivera creado outros mundos — já lá tivera mettido outros padrões de vixtorias, assim é descuidada na posteridade de seu nome: - como se não fosse tam grande louvor dilatal-o por penna, como ganhal-o pela lança»»!)

Falla-nos assim o nosso Tito Livio Portuguez na Decada I, Livr. V, Cap. XI.

Eram justas então estas palavras, sem deixarem de o ser ainda em parte até os nossos dias.

Provêm essa negligencia dos nossos maiores - educados no meio do clangor das tubas guerreiras — da origem tumultuaria da firmação da nossa independencia, roborada no campo da batalha ao estridor fremente das armas.

Cortava então a espada todas as difficuldades do mundo. - Cada um dos nossos maiores era um Alexandre Magno em Gordio na Phrygia.

O bulicio aprasivel das palestras litterarias, convivios feracissimos de fructos valiosos, não era o alvo dos nossos maiores. - Cifravam-se as lettras então n'algumas endeixas de paladino enamorado, e n'alguma canção de poeta cavalleiro.

O nosso paiz foi desencravado da coroa mussulmana á ponta de lança, assim como os outros territorios da peninsula, desde os primeiros arrojos dos heroes de Covadonga nos alcantis das Asturias no século VIII.

Foi assim, que esses gigantes da monarchia goda, salvos da batalha sangrenta do Guadalete, firmaram os lineamentos do reino d'Oviedo, e serviram de modelo patriotico aos nossos maiores no século XII.

Com o volver dos annos, sumiram-se na voragem dos evos as aspirações guerreiras, e assumiram a sua posição outras aspirações sociaes.

Apenas os nossos maiores firmaram a nossa nacionalidade, começaram para $\operatorname{logo}$ a não vêr com bons olhos, que o montante do senhor feudal 
- encastellado no cimo da montanha - pezasse mais que o Codigo das Leis na balança da justiça.

Affervoraram-se então em organisar-se em communas, e cimentaram com perseverança os lineamentos das nossas liberdades municipaes. - Firmaram a emanciação burgueza contra o despotismo senhoreai. - Codificaram assim os germens da soberania popular. - Libertaram em fim das peas do feudalismo, alliados á realeza, o burguezismo enobrecedor do nosso paiz.

Existem ainda vestigios da lucta, entre a feudalidade moribunda e a burguezia nascente, em não poucos dos nossos concelhos, ainda que menos desastrosa que n'outras partes..

Começaram então as lettras a florir entre nós auspiciosas, deixando entrever com fulgor, o como no campo da civilisação — atravez da estrada do futuro - nos daria o progresso um logar d'honra no mundo.

Affeitos ao manejo das armas, empunhamos de nova a espada limpadora das hostes mussulmanas, arrojadas corajosamente do paiz para fóra. -Abrimos com ella penetraes immensos na Africa, na Asia, na America, e na Oceánia, dando logar assim a entrar por elles a civilisação moderna, guiada pelos padrõès que nós alli hasteamos á sombra da Cruz.

Existem ainda alguns d'elles nos sertões que descobrimos, para attestarem ao mundo inteiro, que nós fomos um povo de gigantes, quando outros ainda poucos signaes davam de si.

Quem vir alli esses padrões d'outr'ora, ha que maravilhar-se d'elles, como quem se maravilha das pyramides do Egypto: - collossos de granito, assentes no meio d'um oceano d'areas, de que a maré subterradora não tem refluxo»

Deixamos os nossos lares em abandono, para irmos á descoberta de regiões longinquas: - e concitamos d'esde logo contra nós as invejas dos estranhos, ao mesmo passo que também abrimos a porta ao viver luxuoso.

Seguiram-se então as phases que deviam seguir-se, depois de lançados entre nós ao solo do paiz estes germens sociaes.

Destruiram-se não poucos dos nossos monumentos historicos durante as quadras que bosquejo: - e deixaram-se de prescrutar outros muitos que depois appareceram em varios pontos do paiz.

Não foi senão no século XVIII, no reinado do rei D. João $\mathrm{V}$, que por Decreto de 8 de Dezembro de 1720 se creara entre nós uma associação litteraria, consagrada essencialmente aos estudos historicos do nosso paiz, e com elles á guarda e conservação dos nossos monumentos archeologicos.

Refiro-me á Academia Real da Historia Portugueza, de que foram confirmados os Estatutos em Decreto de 4 de Junho de 1721.

Foi mais tarde, que se inaugurára entre nós também a Academia Real das Sciendas, de que foram confirmados os Estatutos que primeiro tivera, em Aviso de 24 de Dezembro de 1779.-—Promoveu esta inauguração do Duque de Lafões, tio da rainha D .Maria I, varão de provada illustração e dedicado amor da patria. 
$\mathrm{Na}$ Collecção das Memorias da Academia Real da Historia Portugueza, nas publicações de 1733, lê-se impresso um Discurso sobre os antiquissimos e rudes altares que se acham em varias partes de Portugal, e que vulgarmente se chamam antas. - Escreveu-o Martinho de Pina e Proença, e recitou-o em conferencia de 30 de Julho: - e fez-se a impressão d'elle na «Parte Segunda» da Collecção das Memorias do alludido anno.

Foi alli, que pela primeira vez se tractára dos monumentos célticos entre nós, descrevendo-se com individuação á luz da epocha. - Não foi no entanto senão em 1868, que o Dr. Francisco Antonio Pereira da Costa, um dos meus ¿Ilustrados contemporaneos universitários, escrevera á luz da nossa edade um trabalho prestimoso a este respeito.

Tem por titulo Monumentos prehistóricos: noções sobre o estadc prehistórico da terra e do homem, seguidas da descripção d'alguns dólmens ou antas de Portugal, com a traducção franceza de Dathunty.

Foi impresso na typographia da Academia Real das Sciendas de Lisboa, publicando-se em $4 .^{\circ}$ maximo:- e é accompanhado de 3 estampas lithographicas.

Em 8 de Septembro do mesmo anno, n'um «folhetim curioso» da Revolução de Setembro, dá-nos uma relação d'estes monumentos muito numerosa, existentes em Portugal, o nosso estudiosíssimo Dr. José Silvestre Ribeiro. - Memora alem de 300 estando ainda muito pouco prescrutado o paiz a este respeito, como sabem os que são dados ás lettras.

Os que memora o Dr. Pereira da Costa — alem d'uma vintena — são existentes sómente nas visinhanças de Castello de Vide no Alemtejo.

São olhados estes monumentos célticos em geral, como documentos comprovativos dos primeiros povos que vieram invadir os ibéros em nossa peninsula, nos tempos mais antigos a que nos é dado remontar. - Deu-se esta invasão com plausivilidade uns 16 séculos antes da era vulgar.

No Armstrong's Gaelic. Diction, deduz-se a etymologia do nome celladerivação a que não assinto — ou da palavra ceIL, occultar — ou da palavra CEILTACH, assistente nos bosques — ou ainda da palavra coille, significativa de floresta.

Conforme os trabalhos recentes de Steur, na sua Ethnograph. des peupl. de VEurop. avant Jésus-Christ, outra é a etymologia da palavra cella.

Nas linguas do norte da Europa, d'onde vieram mediatamente os cellas para o sul d'ella, exprime-se a qualidade frio pela raiz kell, euphonisada algumas vezes em kalt.

Nos povos de raça indo-germinaica, são usuaes ainda as expressões correlativas d'estas raizes. - Ha no inglez, por exemplo, a palavra colt; no belga e hollandez, a palavra koud; e no allemão, a palavra kalt.

$\mathrm{Na}$ palavra cella, assim como na correlativa kaltaf luz a fusão litteral das raizes kelt e da - significando ambas em lingua céltica povos dos paizes frios - agentes das regiões do norte» - em contraste com os povos dos paizes quentes do sul. 
Seria êrro olhar os nomes keltoi e kéllike, usuaes nos escriptores gregos, como nomes proprios, e não como nomes appellativos. - Nem seria êrro menor, o attribuir-se-lhe ainda uma procedencia hellenica.

Não tem os nomes dos povos primitivos da Europa outra procedencia vocabular, senão a dos nomes appellativos, como palavras indicadoras da situação das suas hordas, e do viver característico de cada uma d'ellas.

Nos escriptores latinos, não são usuaes os nomes kéltoi e kéltiké dos gregos - expressões ainda com a fórma kéltài em Apollodoro. - Acha-se em logar d'estas palavras o nome galli de que os escriptores francezes derivaram o nome gaulezes.

Foi dos insúbros - a tribu mais numerosa dos invasores de Roma, e cognominada então gaalen entre os germanos - que os escriptores da cidade dos septe montes assimilaram para a sua lingua o nome galli.

Não faltam historiadores no entanto, a quem esta palavra não passa d'uma adoptação antonomastica do gallo, de que usavam os gaulezes como emblema nacional. - Olham para isto apenas, como olham para a pomba, emblema dos assyrios e baby- Ionios; para o crocodilo e o hippopotamo emblema dos egypcios; para o boi, emblema dos cimbros, em que nós euphonisamos os kimris; para o dragão, emblema dos chinezes; para a aguia, emblema dos persas e romanos; para o lobo e o tigre, emblema dos germanos e francezes. para o gato, emblema dos alanos; e para a cauda de cavallo, emblema das tribus nómadas do interior da Asia.

Este nome gaalen dos insúbros em geral — vindos do norte da Europa com os seus congéneres d'invasão para as Gallia, d'onde se dirigiram todos ao depois sobre Roma - deriva-se da raíz gaal, a que é equivalente a raiz gael - ambas euphonisadas pela raiz gal.

Significam todas ellas inimigo na lingua céltica: - e são a designação cumulativa dos povos agressores da Europa, distinctos como brancos de pelle e arruivados de cabello, como a nenhum cultor das lettras é licito deixar de crer.

De serem celtas e gallos um e o mesmo povo, acha-se em Cesar um testimunho de toda a prova, ao fallar-nos dos povos das Gallias nos seus Commentario famigerados.

Eis-aqui o contexto a que me refiro: - Quiipsorum linguâ Celtae, nostrâ Galli appellantur.

Não se esqueça no entanto, que não se allude na phrase nostrâ linguâ senão a um nome de novo romanisado: - o que se vê expressamente em Tito Livio, nas phrases correlativas gens nova et novum nomen romanorum.

Resulta o que deixo dicto, do estudo das antiguidades a que os cultores da lettras se têm consagrado modernamente, coadjuvando-se mutuamente nas suas investigações archeologicas, e auxiliando-se prestimosamente dos monumentos archivados nos museus.

Conforme os estudos ulteriores dos ethnógraphos, não são attinentes aos celtas, como se têm crido atégora, os «monumentos rudes e toscos», a que os nossos maiores davam o nomem d 'antas em geral, e a que os estrangeiros dão em geral o nome de dólmens. 
Os archeólogos allemães, e com elles os inglezes e os francezes, olham estes monumentos da primitiva edade de pedra - «estas reliquias cyclopeas venerandas» — como attinentes a povos da raça amarella, que antes da invasão dos celtas estancearam em nossas regiões.

E asserto sem curso entre nós esta opinião ethnographica recente; porque ninguem sonhou nunca até os nossos dias com vestigios primitivos da raça amarella na Europa, e muito especialmente nas suas regiões do sul.

Apesar das concitações de Wormsaae contra estas doutrinas hodiernas, conjuncto com outros sabios do norte; ha de proclamar-se contra elles convictamente, quem se der a lêr a obra de Gobineau, a que elle se consagrára a este respeito com toda a dedicação.

Vêr-se-ha d'este escripto Sur inégalité des races humaines, que não foram os iberos e os celtas, mas «outros povos anteriores a elles», os que n'esta nossa peninsula estancearam como autocthónos. - Eram povos da edade de pedra, a que não pertencem evidentemente os celtas, «raça branca mais illustrada que elles, e que é hoje collocada nas edades de bronze e de ferro pelos archeólogos cultivados dos nossos dias».

Aos argumentos das investigações geológicas e da anatomia comparada — inconcussos na sua especie - accresce ainda uma prova archeologica de valor para o caso.

Os monumentos cyclopeus, a que ninguem contesta a existencia, estendem-se do sul da Europa ao norte pela Dinamarca, pela Suecia, e pela Russia.-Atravessam o Ourai pela Alta-Siberia: - passam o estreito de Behring: penetram nas florestas da America do norte: - descem ás margens do Mississipi: - e na maxima parte d'estas regiões immensas não estancearam os celtas.

Contam por isso 3000 annos d'existencia ao menos - como é plausivel de vêr aos estudiosos de datas - os perlustramentos da nossa peninsula pelos antecessores dos iberos e dos celtas, olhados atégora como os nossos maiores primitivos.

Yê-se d'este quadro que deixo esboçado - e de que me sirvo de preferencia no meio d'outros de que não falho - qual é a prestimosissima utilidade da inauguração d'um Atheneu Archeologico aqui n'esta nossa Braga, para dessiminação mutua d'estes conhecimentos entre nós, e das illucidações accessorias em correlação com elles.

Com o mutuo concurso de todos nós, em cujos corações vive enthusiastico o amor da patria, aprenderemos muitissimo uns dos outros; e daremos a esta capital do Minho - berço natalício para uns, e patria adoptiva para outros - o renome de que ella é crédora, não só como povoação alegre e ridente, circumdada d'um horisonte amplo e vistoso, e coberta por um ceo limpido e fascinador, senão ainda orno repleta de recordações gloriosas em todas as edades, e em todas as phases da historia.

Não é sem espinhos a estrada que vamos trilhar: —- mas nada ha, que os não tenha de sobra, em quanto peregrinamos na terra em que vivemos. 
Removel-os com gloria; ceifal-os em proveito da humanidade; é dos homens inquebrantáveis, a quem o porvir allumia com o facho do progresso nos páramos da civilisação.

O genio da gloria patria, que nos olha como filhos dilectos, brada-nos àvantc a cada um de nós, collocando-nos sob a égide do Venerando Prelado Primaz.

Diz-nos a um por um no intimo do coração, o que o meu finado contemporaneo de Coimbra Antonio Gonçalves Dias - honra da villa de Cachias na provincia do Maranhão - pozera na Canção do Tamoio nos labios do pae a enthusiasmar o filho:

As armas ensaia;

Penetra na vida:

Pezada ou querida,

Viver è luctar.

Se o duro combate,

Os fracos abate;

Aos fortes, aos bravos,

Só póde exaltar.

Braga, 29 de Junho de 1876.

Per eira-Caldas

A Mesa Provisoria ficou composta do Venerando Arcebispo como presidente, e dos snrs. visconde de Pindella como presidente da camara, Deão da Sé Primaz, Director das Obras Publicas, e Professor Pereira-Caldas como secretario.

No fim d'este acto solemne recitaram mimosas e arrebatadoras poesias os snrs. Alfredo Campos, Correia Junior, e Cunha Vianna.

Solicitamos estas poesias, que publicaremos apenas as tenhamos.

Comércio do Minho, 1-7-1876

10. Atheneu archeologico bracarense

Reúne no proximo domingo, no salão do Paço, a meza provisoria do Atheneu archeologico, afim de lhe serem apresentados os estatutos d'aquella sociedade.

Comércio do Minho, 4-7-1876

\section{O Atheneu Archeologico de Braga}

Do seio da nossa obscuridade soltaremos também um brado de approvação ao proveitoso commettimento, que acaba de realisar-se em Braga. Saudamos com jubilosa esperança a inauguração do Atheneu Archeologico 
(Testa cidade, e antevemos os proficuos resultados, que para o estudo das antiguidades patrias, tão descurado entre nós, devem advir da existencia d'este novo estádio aberto ás intelligencias, que em gloriosos e inoffensivos certames poderão d'ora avante disputar alli os premios devidos à illustração, e ao estudo, com que esta se adquire.

Não tentaremos agora encarecer a importancia da Archeologia. Penna muito mais hábil, que a nossa, acaba de fazel-o proficientemente na circular para o convite do Atheneu Archeologico. Limitar-nos-hemos pois sómente a affirmar, que é lamentável, é vergonhosa mesmo a incuria, com que temos olhado até hoje para a conservação e estudo dos nossos monumentos; e não menos vergonhosa é a ignorancia, que se nota em escriptores nossos, aliás eruditos, ácerca das antiguidades patrias, e dos auctores classicos, com o auxilio de cujas obras podémos investigabas.

Pedimos venia para fazer algumas citações comprovativas do que acabamos de dizer.

Publicou-se recentemente, sob o venerando nome de Fr. Domingos Vieira, um Diccionario da lingua Portugueza; á frente do $1 .^{\circ}$ tomo d'este imprimiu-se um trabalho sobre a mesma lingua, escripto por um mancebo, que gosa ahi da reputação de muito erudito. Ora a paginas 198 d'essa introdução lê-se o seguinte:

«Não se pode determinar com certeza qual foi a segunda camada de habitadores da Hispanha. A passagem de Ligures entre os Ibéris e os Celtas, com quanto possi vel, não ha nenhum testimunho historico, que nol-a faça olhar como provável».

O periodo, que transcrevemos em itálico, revela a mais crassa ignorancia dos testimunhos historicos, legados pela antiguidade, ácerca dos primeiros habitadores da Peninsula Ibérica. Se o escriptor citado houvesse lido Estrabão, Avieno, e outros escriptores antigos, saberia por certo, que os Ligures eram propriamente de raça ibéra, que a primitiva estancia dos Ligures e a sua cidade de Lygilina ficava não longe do Tartessus (Gibraltar); que d'alli foram expulsos pela invasão dos Celtas, e obrigados a emigrar para á Gallia e Italia, impedindo também diante d'elles os Sicanos — outro povo de procedencia ibérica - que Thucydides colloca igualmente em Hispanha, nas margens do Ségre, e que d'alli passaram a habitar Sicilia.

Em face de todos estes testimunhos dos auctores gregos e romanos só a insciencia mais indesculpável pode ousadamente affirmar que - não ha nenhum testimunho historico que tios faça olhar coniG provável (!!) a passagem de Ligures entre Ibéros e Celtas.

No volume IV do Archivo Pittoresco ha um artigo do snr. Manoel da Gama Xaro (que é justamente reputado como um dos nossos mais distintos antiquarios) ácerca dos habitantes de Cetobriga anteriores aos Romanos. Ahi sustenta elle, que a costa da Lusitania, delimitada pelo Tejo e pelo Guadiana (Tagus e Ana) fora habitada pelos Bastulos, opinião singular, que tem indusido depois em erro a varios escriptores, entre os quaes o estimável e infatigável auctor do Portugal antigo e moderno. 
E sobre que dados fundava o snr. Xaro esta sua opinião de todo o ponto inexacta? Sobre urna simples passagem de Plinio, que se esqueceu de comparar com outras passagens do mesmo geographo, e sobretudo com os textos de Estrabão e de Pomponio Méla.

Plinio diz: Ab Ana autem Atlantico Oceano obversa, Bastulorum Turdulorumque est.. E o snr. Xaro accrescenta: «Ternos portanto Bastulos e Turdulos desde a foz do Guadiana por toda a costa do Oceano, até onde?» - Se consultasse a Pomponio Méla, acharia esta sua questão resolvida de uma maneira bem differente d'aquella, por que elle erradamente a resolveu. Pomponio escreve assim: "Ao sahir do Estreito (de Gibraltar) sobre a direita, topa-se com a costa occidental da Betica que... apresenta uma linha recta até ao Ana. Aqui habitam os Turdulos e os Bastulos»-Logo os Bártulos eram povos da Betica e não da Lusitania, e estanceavam a Leste e não a Oeste do Ana, que formava a linha divisória entre as duas provincias.

Estrabão concorda perfeitamente com Pomponio Méla. «Entre a parte do littoral ibérico (diz elle), em que se abrem as fozes do Betis e do Ana, e a extremidade da Maurosia, uma irrupção do mar Atlantico formou o estreito das columnas d'Hercules, que hoje dá communicação entre o mar exterior e o interior. Ora alii proximo, no territorio dos Ibéros Bastamos, também denominados Bastulos, está o monte Calpe, etc.».

E n'outro logar: «A Turdetania tem por limites a O. e N. o curso do Ana... ao sul enfim essa estreita faxa de térra comprehendida entre Calpe e Gadir a (Cadix), que é occupada por urna parte da nação bastetana, e depois o proprio mar até ao Ana».

E o snr. Gama Xaro leu tão mal esta passagem do geographo grego, que na estreita faxa de terra, tão bem determinada por elle, viu o terreno de Troia, entre o rio Sádo e o mar» aliquando bonus dormitai...

Não nos surprehendem estes lapsos, proprios da debilidade da nossa natureza tão subjeita ao erro. Lamentamos porém que tão inexactas opiniões hajam passado em julgado, e sejam ahi admitidas como irrefragaveis por toda a gente; o que prova o abatimento, a que entre nós hão descido os estudos das antiguidades patrias, e a especie de despreso, com que são olhadas no nosso paiz as investigações archeologicas, a que lá fóra se está hoje ligando tão subida attençâo.

Graças pois á nobre empreza, a que ardidamente se votaram os dignissimos instituidores do Atheneu Archeologico bracarense. Que os seus nobilissimos exforços seja secundados por todos os que em Portugal cultivam a verdadeira sciencia, e que d'elle resulte o maximo proveito para as lettras patrais, eis os votos sinceros, que não cessará de fazer o humilde signatario d'estas mal traçadas linhas.

D. M. Sotto-Mayor Comércio do Minho, 11-7-1876 


\title{
12. Atheneu Archeologico Bracarense
}

No domingo 9 reuniu-se nos paços archiepiscopaes a Meza Provisoria do Atheneu Archeologico Bracarense.

Discutiu na generalidade os Estatutos da associação: e no domingo seguinte começa a sua discussão na especialidade, assim como a discussão dos Regulamentos respectivos.

Os Estatutos, e os Regulamentos são modelados pelos dos estabelecimentos analogos que temos na Europa.

A não haver ante-hontem a procissão do Carmo, que é uma das principaes desta terra, ter-se-hia n'este dia começado as discussões na especialidade.

\author{
Comércio do Minho, 18-7-1876
}

\section{Achado}

Nos desaterros a que se está procedendo aqui em Braga, na rua aberta de novo entre a antiga torre de S. Bento e a rua nova da Sé, achou-se uma communicação subterranea de torre a torre, pertencente ás fortificações primittivas da cidade, devidas ao reinado d'el rei D. Diniz.

Eram 8 as portas que n'essa epocha tinha Braga, ligadas umas a outras por muralhas fortes, no gosto da epocha a que pertenciam.

Nos annos de 1375, reedificou estas muralhas el-rei D. Fernando enobrecendo-as com novas torres vigorosas.

No interior d'esta circumvalação, havia um forte castello, que ainda hoje realça donairoso o aspecto da cidade, a quem a observa do passeio de Sant'Anna para o occidente.

Este aqueducto anda se limpando na altura de um homem, e tencionam aproveital-o para o escoadouro das agoas do campo de S. Sebastião, e mesmo da nova rua que a camara vae alinhar para o largo do Collegio de S. Paulo.

Comércio do Minho, 9-3-1876

\section{Cippo}

Nas escavações a que se anda procedendo para escoadouro das aguas na rua da Misericordia, appareceu um grande cippo, a prumo sobre base. O local ficava por debaixo das casas que se demoliram para o alargamento d'aquella rua, - o que prova que a edificação da mesma foi feita sobre base antiga e pavimento muito mais baixo. 
15. Congresso Internacional d'Anthr op ologia e de Archeologia prehistórica

Tem de abrir-se em Lisboa este anno, a 20 de setembro, fechando-se a 29 do mesmo.

E' a nona sessão, de que é presidente o exc. ${ }^{\text {mo }}$ Andrade Corvo e secretario geral o exc. ${ }^{\text {mo }}$ Carlos Ribeiro; aquelle, ministro dos extrangeiros no governo da regeneração; e este, deputado na actual legislatura.

São numerosos os membros correspondentes d'este Congresso; pertencem á Allemanha, á Austria, á Belgica, á Dinamarca, á Hespanha, a Finlandia, á França, á Grã-Bretanha Irlanda, á Grecia, á Hongria, á Italia, ao Luxemburgo, á Noruega, aos Paizes Baixos, á Romania, á Russia, á Suecia, á Suissa, á Turquia, ao Egypto, ao Cabo da Boa Esperança, á India, á Australia, aos Estados Unidos da America, ao Canadá, ás Bermudas, ao Porto Rico, a Nicaragoa, á Republica Argetina, ao Chili, e ao Brasil.

Dos membros correspondentes nacionaes, representam esta Cidade de Braga no Congresso os seguintes:

Adolpho Pimentel.

Antonio Brandão.

Fernando Castiço.

Jeronymo Pimentel.

Pereira Caldas.

Comércio do Minho, 18-3-1880

\section{Archeologia}

Em S. Martinho de Dume, suburbios d'esta cidade procedendo-se á abertura d'um poço, foram encontradas varias medalhas d'uma alta antiguidade, esqueletos, varios capiteis jonicos e um formoso fuste de columna.

Alguns amadores da archeologia reuniram no domingo, para examinar os objectos encontrados.

Comércio do Alinho, 3-4-1883

17 ' Moedas antigas

Nas escavações a que se está procedendo na rua do Cabbido, tem-se encontrado grande numero de antigas moedas de subido valor archeologico.

Comércio do Alinho, 5-7-1883

18. Alosaicos

Fomos brindados pelo nosso distincto amigo ex. ${ }^{\text {mò }}$ snr. dr. Pereira Caldas, .jIlustrado--.professor, do Lyceu de Braga, com duas photographias 
representando as ruinas de dous pavimentos de mosaico, encontrados ñas excavações a que se tem procedido para a construcção dos alicerces do novo seminario dos Orphãos de S. Caetano.

Os mosaicos são feitos de marmores de varias cores; o fundo é feito de lioz de Pero Pinheiro.

Uma das photographias é um valioso espécimen do que os romanos denominavam pavimenta sectilia.

A outra é bellissima também, porem, menos primorosa: os romanos davam-lhe o nome de pavimenta tessellata.

Ambas representam o fundo de duas piscinas, urna (a mais primorosa), de recreio, e outra de deposito de aguas, a que os romanos chamavam piscina subdialia.

As photographias foram tiradas com a maxima nitidez e perfeição pelo snr. Cezar Lima, photographo da casa filial de Sola \& C. ${ }^{\circ}$, estabelecida n'esta cidade, á custa do snr. Pereira Caldas, distincto amador d'estes primores, notáveis pelo seu valor artistico e pela sua antiguidade.

Comércio do Minho, 19-1-1884

\section{Lápide romana inédita}

I. - Em 28 do Agosto findo, achou-se aqui em Braga uma lapide romana - entre uns entulhos d'um cano d'esgóto - ao lado da egreja matriz de S. João do Souto, e defronte da direcção geral das obras publicas do districto.

E' uma lapide inédita ainda - e duplamente valiosa, por isso mesmo, para a historia da epigraphia romana em Braga.

II. - Eis-aqui o contexto lapidar d'esta columneta emoldurada, com 0,64 de altura - 0,24 de largura central - e 0,29 nas duas bases, tudo em forma regularmente quadrangular, e com engaste no cimo para uma divindade:

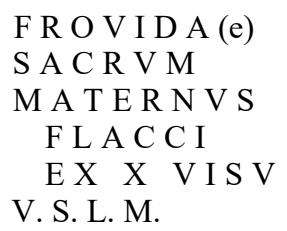

III. - Eis-aqui a licção corrente d'esta inscripção, em que formam uma sigla de ligação, na linha terceira, o $T$ e o $E$ de MATERNVS: FROVIDAE. SACRVM. MATERNVS. FLACCI, (filius). EX. VISV. V (otvm). S (olvit) L (ibens). M (erito):

(Monumento) consagrado a Frovida: Materno, filho de Flacco — em virtude d'uma visão - de bom grado cumpriu este voto.

Conimbriga, 24 (1985), 5-83 
IV. - O nome da divindade Frovida — claramente gravado na lapide — da meritos lapidares a esta columneta inédita.

E' um nome ritual mais, entre os não poucos de divindades pre-romanas, de que de dia em dia augmentam a lista os novos achados.

V. —Lapides votivas — com a designação EX VOTO expressa — não há quasi dia, em que não appareçam aqui e alii sobterradas - - alem das conhecidas em geral.

Com a formula EX VISV, não são por aqui em Braga usuaes as lapides - assim como o não são também com as formulas EX VOTO SVSCEPTO, EX VOTO PVBLICO, EX RELIGIONE, EX IVSSV NVMINIS, e EX PONTIFICIS IVSSV, alem das formulas EX VOTO SOLVTO, e EX ORACVLO.

Em Argote nas Memorias de Braga - Tom. I. Num. 381-acha-se a formula epigraphica EX PRAECEPTO, em consagração ao Deus Evento.

VI. - Os Maternos e os Matérmanos - assim como os Flaccos e os Flacos, alem dos Flaccinso ainda — são personagens frequentes na lapidaria romana da peninsula hispánica.

Nem raras são também as Maternas tam pouco - embora menos usuaes que os Maternos e os Maternianos.

Braga, 3 Septembro 1885.

O Professor do Lyceu, Per eira-Caldas

A Abelha, 6-9-1885 e Comércio do Minho, 8-9-1885

\section{Descoberta archeologica}

N'um pequeno beco que se anda a alargar e que desemboca na rua da Cruz de Pedra, foi encontrado, nos escombros d'uma casa velha, um monte de ladrilhos sobrepostos, e presos com argamassa romana. Suppõe-se que aquillo era o pé d'alguma estatua; D. Rodrigo de Moura refere-se a ella. Noticiaremos mais d'espaço

Comércio do Minho, 29-5-1886

\section{Moedas romanas}

Em umas obras que o snr. Fernando Castiço mandou fazer junto á torre do seminario, appareceram algumas moedas romanas, com os cunhos bem visiveis, mas completamente cobertas de verdete. 


\section{Mais antiguidades}

Nas obras a que o snr. Fernando Castiço anda procedendo no seu quintal, proximo ao seminario, foi encontrado últimamente, a uma profundidade de tres metros, um rolete de moedas de cobre do tempo dos romanos, e tambem dous bronzes do mesmo tempo. Todas estas moedas, que são em numero de 10 ou 12, estavam cobertas de verdete que mal deixa ver os cunhos do dinheiro.

Comércio do Minho, 6-11-1886

\section{Moedas antigas}

Numa casa da rua dos Sapateiros que se anda a reedificar, pertencente ao snr. Paulino Evaristo da Rocha, digno sollicitador do foro de Braga, foram encontradas, n'um esconderijo, grande porção de moedas antigas, no valor de $900 \$ 000$ reis.

Comércio do Minho, 20-9-1887

\section{Thesouro sim, dinheiro não}

Desmente-se a noticia que circulou n'esta cidade, de haver o snr. Paulino Evaristo da Rocha encontrado n'uma casa que anda reedificando na rúa dos Sapateiros, um thesouro com moedas de ouro antigas, no valor de $900 \$ 000$ reis.

Parece que o snr. Paulino encontrou só o sitio do dinheiro, cheio de pó e teias de aranha.

Que desapontamento.

Damos sinceros pésames ao nosso amigo snr. Paulino, pois do coração desejávamos que encontrasse não só o sitio, mas o thesouro repleto de bagalhoça, contendo pelo menos, 900:000\$000 reis.

Comércio do Minho, 22-9-1887

\section{Moedas antigas}

Não foi exacta ainda a noticia que demos no numero passado, ácerca do tehsouro encontrado pelo snr. Paulino Evaristo da Rocha na casa que traz em reconstrução na antiga rua dos Sapateiros.

As ultimas averiguações dão o seguinte resultado:

E' verdade que appareceu o cofre onde devera estar dinheiro, muito dinheiro talvez; mas tambem é verdade que esse cofre ou thesouro não continha apenas pó e teias de aranha. 
Appareceram algumas moedas de ouro, antiquissimas e em perfeito estado de conservação, com legendas distinctas e effigies magnificamente cunhadas.

O valor feal d'estas moedas não é de $900 \$ 000$ reis, nem sequer se approxima d'essa quantia; porém o valor estimativo é muito superior, e eremos que o snr. Paulino poderia, querendo vendel-as, apurar muito mais de $900 \$ 000$ reis.

Consta-nos, porém, que o snr. Paulino não as venderá por preço nenhum, porque deseja guardal-as como merecem.

Aos museus e colleccionadores de antiguidades conviria muito a acquisição d'algumas d'estas moedas, que na realidade são preciosas; pena é que o possuidor não as offereça a qualquer instituição d'este genero, pois estamos certos de que seriam devidamente apreciadas.

A'quelles que se gloriaram por nós havermos dado uma noticia falsa, respondemos agora que cantaram cedo de mais, pois a blague só existe no valor real de $900 \$ 000$ reis que attribuiramos ás moedas antigas, quando o seu valor é todo estimativo.

Erramos n'este ponto, é verdade; mas quem ha que não erre?

Errare humanum est.

Comércio do Minho, 24-9-1887

\section{Moedas romanas}

Diz a «Palavra»: «O dono do predio da cidade de Braga, onde ha dias foi encontrado um grande cofre contendo moedas de oiro romanas, vae mandal-as ao snr. dr. Aragão, afim d'este cavalheiro as classificar e apreciar».

Comércio do Minho, 1-10-1887

\section{Moedas antigas}

Nas escavações a que se anda procedendo junto da egreja das Carvalheiras, para o nivelamento da rua de S. Sebastião, teem apparecido algumas moedas antigas, bem como columnas de pedra e outros objectos d'arte, que alguém diz pertencerem ás velhas muralhas da cidade.

Um operario vendeu uma d'essas moedas a um transeunte, pela modica quantia de 200 réis.

Comércio do Minho, 30-4-1889

\section{Museu archeologico}

A camara municipal d'este concelho deliberou organisar um museu archeologico no logar das Carvalheiras.

Conimbriga, 24 (1985), 5-83 
Foi encarregado d'este serviço o snr. dr. José de Sousa Machado, digno secretario da camara.

Os trabalhos para o museu já principiaram.

N'elle vão ser collocados o antigo pelourinho da cidade, armas de edifícios publicos, cruzeiros, pedras com inscripções apparecidas ultimamente, etc..

Comércio do Minho, 4-2-1892

29. Moedas antigas

Nas escavações a que se anda procedendo no bairro das Travessas, para a edificação de predios, teem apparecido algumas moedas d'oiro, de grande valor estimativo.

Os operarios que as teem achado, vendem-as por um preço diminuto.

Vimos hontem 3 moedas, bem conservadas, que foram compradas por uns $10 \$ 000$ réis; pois já offereceram por ellas mais de $60 \$ 000$.

Duas são romanas e teem em volta da efigie a seguinte inscripção: D. N. HONORIVS. P. F. AVG. AYR.

Comércio do Minho, 4-6-1892

30. Dinheiro antigo

$\mathrm{Na}$ tarde de quarta-feira appareceu uma talha de barro com muitas moedas antigas, nas escavações a que se anda procedendo na antiga rua do Coelho, para o encanamento de aguas.

As moedas são de cobre e pesam cerca de 80 kilos.

A camara municipal d'este concelho tomou posse d'este thesouro.

Comércio do Minho, 16-7-1892

31. Subterraneo

Parece que na antiga rua do Coelho, onde ha pouco appareceram muitas moedas antigas, existe um subterraneo.

A ex. ${ }^{\text {ma }}$ camara vae mandar proceder a excavações.

Comércio do Minho, 23-7-1892

Conimbriga, 24 (1985), 5-83 
32. Moedas romanas

O snr. dr. Francisco Sarmento offereceu uma collecção de moedas romanas das que foram achadas últimamente nas escavações da antiga rua do Coelho, d'esta cidade, ao museu de archeologia e numismática de Guimarães.

Comércio do Minho, 2-8-1892

\section{3, Inscripções e lettreiros}

Com o titulo de «Inscripções e lettreiros da cidade de Braga e algumas freguezias ruraes», acaba de sair á luz um volume de 182 paginas, impresso em bom papel e subscripto pelo nosso amigo snr. Albino Bellino.

Como o titulo indica, o livro contém zincographias das inscripções e lettreiros que se encontram nas egrejas, capellas, conventos, fontes e antigos edificios de Braga e seus arredores, acompanhadas de curiosas indicações sobre a fundação e phases por que passaram estes monumentos, algumas sabidas já, outras corrigidas e ampliadas, muitas ignoradas até agora e todas de grande valor como subsidios para a historia d'esta cidade.

Em seguida a um pequeno prologo do auctor vem uma carta-prefácio do snr. dr. Pereira Caldas. A obra é offerecida á Real Associação dos Architectos Civis e Archeologos Portuguezes, á Sociedade de Geographia de Lisboa e á Associação Patriotica Primeiro de Dezembro, de que o snr. Albano Bellino é socio. Insere o retracto do auctor, em phototypia, ostentando as insignias d'aquellas tres aggremiações. livrarias.

O preço da obra é 600 réis, e encontra-se à venda nas principaes

Dando sinceros parabéns ao snr. Albano Bellino pelo exito do seu livro, ao qual os entendidos teem feito plena justiça, agredecemos-lhe penhoradamente a offerta de um exemplar e a amabilidade da dedicatoria com que nos distinguiu.

Comércio do Minho, 10-9-1895

\section{Archeologia}

$\mathrm{Na}$ sua faina constante de investigador archeologo, acaba de encontrar n'esta cidade mais algumas inscripções inéditas romanas e visigóticas, o nosso amigo snr. Albano Bellino.

Está fazendo um estudo que por estes dias entregará ao prélo, porque, segundo informações que temos, estas inscripções são, como as do seu ultimo livro, de altissimo valor epigraphico. 
Que o snr. Bellino trabalha com boa vontade e orientação scientifica, prova o facto de encontrar estas ultimas lapides poucos dias depois de visitar Braga em procura de velharias o sr. Leite de Vasconcellos, de Lisboa, acompanhado de varios individuos d'aqui.

Comércio do Minho, 11-4-1896

\section{5. Мuzeu archeologico}

O reo. P.e Martins Capella, presidente da commissão encarregada pela camara municipal de proceder á installação d'um muzeu archeologico junto á escola industrial d'esta cidade, propoz que á referida commissão fossem aggregados os snrs. Albano Bellino e dr. Pereira Caldas.

Comércio do Minho, 4-3-1897

36. Monumentos nacionaes

Alguns jornaes noticiaram ha tempos que o nosso amigo snr. Albano Bellino fora nomeado vogal correspondente da commissão dos monumentos nacionaes nas Taipas.

Essa noticia carecia, porém, de fundamento, visto que o dedicado archeologo acaba de receber do ministerio das obras publicas o diploma da sua nomeação para o cargo de vogal correspondente da commissão dos monumentos nacionaes em Braga, e d'esta commissão um officio convidando-o a indicar os monumentos que n'esta cidade têem de ser considerados nacionaes.

Endereçamos sinceros parabéns ao nosso amigo pelo frisante testimunho de apreço que vem de ser-lhe conferido.

Comércio do Minho, 30-3-1897

\section{Alhano Bellino}

Este nosso presado amigo e incansável archeologo foi últimamente nomeado socio de merito da Sociedade Archeologica de Pontevedra (Hespanha), em attenção aos serviços prestados ao museu d'aquella sociedade.

Enviamos ao nosso amigo cordeaes felicitações pela distincção que lhe foi conferida. 


\section{Archeologia portugueza}

Na ultima sessão da Real Associação dos Architectos Civis e Archeologos Portuguezes foram votados socios, além d'outros, os snrs. Ernesto Korrodi, que foi professor na escola industrial de Braga, drs. Accacio da Silva Guimarães, José Joaquim dos Santos Motta e padre Manoel José Pereira, professores do lyceu d'esta cidade.

Comércio do Minho, 31-3-1898

\section{Uma cividade romana}

O nosso talentoso amigo e infatigável archeologo snr. Albano Bellino, que últimamente tem effectuado varias excursões archeologicas, n'este e n'outros concelhos proximos, encontrou a uma legua de Braga, para os lados de Guizande e Veiga, uma estação luzo-romana (cividade) que se lhe afigura de altissima importancia, a avaliar pelos fragmentos de cerámica e tegulae que de lá trouxe para o seu museu particular.

O snr. Bellino, que também colheu uma inscripção romana inedita, tem muita confiança na exploração, que deve produzir optimos resultados. $\mathrm{Na}$ mesma occasião tomou conhecimento d'outra antiga povoação fortificada, aqui nas proximidades de Braga.

Comércio do Minho, 25-4-1899

\section{Achados archeologicos}

O nosso presado amigo snr. Albano Bellino obteve já dos proprietarios do respectivo terreno a auctorisação necessaria para proceder a explorações no monte denominado de Christello, para os lados da Veiga de Penso, onde o estudioso archeologo descobriu ha dias indicios d'uma antiga estação luso-romana, de altissima importancia.

O snr. Bellino vae em breve dar começo aos seus trabalhos de invesinvestigação.

Comércio do Minho, 2:5-T899

\section{Explorações archeologicas}

A Associação dos Archeologos Portuguezes, tendo lido em sessão um officio do nosso amigo snr. Albano Bellino, em que pede auxilio pecuniario para proseguir as suas explorações archeologicas nos arredores d'esta cidade, deli- 
berou-se responder que a associação ia officiar á camara de Braga para lhe prestar todo o auxilio, visto que os recursos da associação não permittiam conceder qualquer auxilio pecuniario.

Comércio do Minho, 27-5-1899

\section{Archeologia}

O snr. Manoel Simões Braga, zeloso juiz da irmandade de Santa Martha, vae hoje com o snr. Albano Bellino ao alto do monte onde brevemente devem principiar as explorações archeologicas a que já nos referimos.

Comércio do Minho, 17-6-1899

\section{Archeologia}

O snr. João Antonio Gonçalves Braga, que foi socio da firma commercial - Valença, Filhos \& C. ${ }^{a}$, possuidor de todo o terreno em que se acha construida a 2, ${ }^{\text {a }}$ muralha da cividade romana no monte da Santa Martha, auctorisou bizarramente o nosso amigo snr. Albano Bellino a mandar proceder ás necessarias escavações archeologicas no referido terreno.

Este offerecimento é de grandissimo alcance, porque o maior numero das construções circulares e quadrilongas encontra-se na área pertencente áquelle proprietario. cimento.

E' digno de louvor o snr. Gonçalves Braga pelo seu patriotico offere-

$\mathrm{Na}$ proxima semana vão proseguir com actividade as escavações archeologicas, devendo ser occupados n'ellas os cantoneiros municipaes.

Comércio do Minho, 8-7-1899

\section{Moedas romanas}

Nas escavações archeologicas a que se anda procedendo na Falperra, sob a direcção do nosso amigo snr. Albano Bellino, foram encontradas algumas moedas romanas.

$$
\text { Comércio do Minho, 1-8-1899 }
$$

\section{Descobertas archeologicas}

O nosso estimável amigo e estudioso archeologo snr. Albano Bellino interrompeu por algum tempo os trabalhos a que andava procedendo no 
monte da Falperra e passou a explorar o monte de S. Mamede, ñas proximidades da freguezia de Guisande, d'este concelho. D'ahi resultou já a descoberta de importantes vestigios d'uma praça da dominação romana, encontrando-se longas paredes e casas circulares, com o competente lastro, fragamentos de tijolos, grandes telhas, etc..

O snr. Bellino espera que dentro de alguns dias esteja visivel urna grande parte do espaço de duas muralhas, para depois apresentar a sua opinião sobre a descoberta que acaba de verificar.

O snr. Torquato Alvares Ribeiro, proprietário do terreno em exploração, não só concedeu auctorisação para se proceder n'elle aos respectivos trabalhos, como auxilia com jornaleiros seus as escavações archeollgicas. Torna-se por isso digno dos mais alevantados encomios.

Comércio do Minho, 31-8-1899

\section{Museu archeologico}

Sua ex. ${ }^{\text {a rev. }}{ }^{\text {ma }}$ o snr. arcebispo primaz cedeu ao nosso amigo snr. Albano Bellino uma loja do paço archiepiscopal para alli recolher todos os objectos do seu museu particular, que se compõe d'alguns dos mais notáveis monumentos epigraphicos da epocha romana, muitos framentos de cerámica, alguns mosaicos, tijolos, machados de pedra, etc.

Tudo isto não tem por emquanto uma disposição apropriada, mas póde desde já considerar-se o inicio d'um futuro museu de alta importancia para a capital do Minho.

Crê-mos, pois, removida uma antiga difficuldade, porque o snr. Bellino, com o producto da exploração das duas cividades romanas que vae pondo a descoberto nas visinhanças de Braga, ha-de enriquecer o referido museu, que representa mais uma prova da sua dedicação extraordinaria por tão pesados estudos.

Comércio do Minho, 16-9-1899

\section{Archeologia}

A expensas do snr. Torquato Alvares Ribeiro, do Porto, e sob a direcção do estudioso archeologo bracarense e nosso amigo snr. Albano Bellino, recomeçaram ha dias os trabalhos de exploração no Mónte Redondo, freguezia de Guizande d'este concelho.

Nas escavações têem apparecido algumas moedas de cobre romanas e portuguezas dos primeiros reinados. Este facto é importantíssimo para a historia d'aquella cidade morta. 
E' muito para louvar o auxilio pecuniario que o snr. Torquato Ribeiro, um dos maiores proprietarios d'aquelles sitios, tem prestado ao snr. Albano Bellino.

Comércio do Minho, 18-9-1900

48. Museu archeologico

A este florescente museu, fundado pelo nosso amigo snr. Albano Bellino, foram últimamente offreecidos os objectos seguintes:

Um capital da Ordem corinthia e dois dos séculos xn e xiv, provenientes do antigo convento de Tibaes - offerta do snr. commendador J. A. Vieira Marques.

Uma lapide com inscripção romana tumular — offerta do snr. commendador Domingos José Ferreira Braga.

Outra lapide com inscripção romana, votiva - offerta do snr. Antonio da Cunha Araujo Braga.

Um fragmento de mosaico romano encontrado nas escavações da rua de S. Thiago - offerta do snr. José Alves Lorôto.

Varias moedas de cobre e um peso de tear romano-offerta do snr. Ferreira Torres.

Uma estatua colossal de granito - offerta da snr. ${ }^{a}$ D. Francisca Xavier Machado.

Duas mós manuarias e um pedaço de muralha romana - offerta do snr. Vasco Jacome de Souza Pereira de Vasconcellos (Avellar).

Dois tijolos dos banhos romanos de Vizella - offerta do snr. dr. Abilio Torres.

Estatua de granito fino, representando um bispo - offerta do snr. Simão Ventura da Luz Pinheiro, por intermedio dos snrs. Antonio d'Araujo Torres e Antonio Mendes Ribeiro.

Um grande tijolo de encanamento romano, encontrado no desaterró da antiga rua do Coelho - offerta do snr. Antonio de Lemos Amorim.

Comércio do Minho, 9-10-1900

\section{Publicações}

Archeologia Christã, por Albano Bellino. E' mais um bom volume com que o distincto antiquario enriquece as letras patrias. Trabalhador incansável e consciencioso, o snr. Albano Bellino tem trazido ao conhecimento do publico a riqueza archeologia de Braga e Guimarães. No presente livro véem mangíficas photogravuras dos principaes monumentos das duas cidades, acompanhadas de descripções em que se corrigem muitos erros e se esclarecem muitos pontos até agora duvidosos. Sirva de exemplo o sino de S. Geraldo, da Sé 
Primaz, cuja complicada inscripção o dedicado investigador teve a paciencia de copiar integralmente, tendo para isso de mandar construir sobre a balaustrada da cupula da torre urna estada de madeira, á qual subiu, volteando 3 vezes o sino para que não lhe escapasse a minima letra ou sinal gravado no bronze. Louvável e pouco vulgar dedicação pela verdade historica!

Além do merecimento archeologico do livro do snr. Albano Bellino, avultam n'elle os synchronismos dos séculos, em que o illustre auctor semeia vasta erudição recheiando-os de curiosissimos factos historicos, esquecidos por alguma gente e ignorados por muita mais. Bastava esta parte do livro para o tornar interessante e digno de ser lido, archivado e consultado. Mas tem ainda outra qualidade valiosa e recommendal-o: é a indicação de todas as egrejas, capellas, oratorios e cruzeiros de Braga e Guimarães, dizendo acerca de cada um o que de mais notável consta sobre a sua origem, fundação, vicissitudes por que passou, factos historicos que com elle se prendem, inscriçpões que contém, solemnidades que n'elle se realisam, etc., etc., de fórma que qualquer visitante d'alguma ou d'ambas as cidades encontra alli um guia mangifico a libertal-o das erradas informações e exageros encomiásticos de cicerones pouco illustrados.

Comércio do Minho, 14-1-1902

\section{Archeologia}

O snr. Visconde da Torre fez doação ao Museu Ethnologico Portuguez de duas estatuas romanas de marmore, de subido valor archeologico, existentes, pelo menos ha dous séculos, na sua quinta titular.

Comércio do Minho, 11-3-1902

\section{1; Câmara Municipal}

Deliberou auctorisar o snr. Albano Bellino a remover para o seu museu archeologico uma lapide romana que está nas proximidades do palacete do snr. conde de S. Martinho.

Comércio do Minho, 29-7-1902

\section{Museu archeologico}

No extracto que fizemos da ultima sessão camararia lê-se que o snr. Albano Bellino foi auctorisado a remover para o seu museu archeologico, estabelecido nos baixos do Paço Archiepiscopal, uma inscripção lapidar que ha muito se encontra abandonada no largo das Carvalheiras. 
A camara é digna dos maiores elogios por ter d'este modo provido á conservação d'aquelle monumento, pois do contrario não tardaria a desapparecer d'alli, como por vezes tem acontecido com outros objectos que accusam a antiguidade e importanda d'esta cidade augusta.

A nosso vêr a camara deveria fazer transportar para o referido museu do snr. Bellino os capiteis, as columnas, os escudos e os baldaquinos que o rapasio dia a dia vae mutilando no primeiro quarteirão da alameda, onde se encontram a granel.

Só assim, com o concurso de todos, poderá ir por diante a fundação definitiva d'um museu em Braga.

Comércio do Minho, 31-7-1902

\section{Archeologia}

A instancias do nosso amigo snr. Albano Bellino, estudioso archeologo bracarense, foi removida para o seu museu archeologico uma lapide votiva dedicada ao deus Júpiter, existente na alvenaria d'uma escada da rua de S. Vicente.

Comércio do Minho, 20-11-1902

54. Associação dos Architectos e Archeologos

Foram eleitos socios correspondentes da Associação dos Architectos e Archeologos Portuguezes os revs, conego Antonio José da Silva Correia Simões, José Martins Barreto Junior e abbade José do Egypto Vieira, bem como o snr. dr. Francisco José de Faria, todos d'esta cidade.

Comércio do Minho, 3-1-1903

55. Um Museu

No «Jornal de Noticias», do dia 12 do corrente, lê-se o seguinte que transcrevemos para mais uma vez por este meio extranharmos a falta de patriorismo que a este respeito se nota em Braga:

«Segundo o informe de amigo nosso que visitou recentemente a cidade de Bragança, o Museu Municipal tem já hoje um destaque notável, entre os estabelecimentos congeneres do paiz. Installado ha poucos annos pela iniciativa intelligente do capitão Albino dos Santos Pereira Lopo, o valioso 
archivo archeologico progride rapidamente, favoneado pela sympathia publica amparado pelos constantes disvellos do zeloso archeographo brigantino. A propaganda intensa do benemérito instituidor fructifica depressa; as offertas affuem e o museu opulenta-se dia a dia, pelo concurso de todo o districto, com crescente numero de padrões venerandos das velhas culturas indigenas.

Impossivel compendiar em breve noticia a serie complexa de monumentos archaicos, exhibidos na acanhada sala cedida pelo senado brigantino. Pelo chão, nas paredes, em montras, agglomeram-se dezenas de objectos interessantíssimos, testimunhos da antiguidade historica e ante-historica da região. $\mathrm{O}$ archeologo, o ethnographo e até o naturalista tem ahi largo thema de estudo. Acham-se representadas mais ou menos abundantemente todas as edades, porque evolucionou a provinda transmontana - a da pedra polida, a do bronze e a do ferro; e sobretudo a phase mais recente da civilisação callaico-romana. E' distincta em especial a serie lapidar: em numerosas estellas, aras, cippos e marcos milliarios lêem-se originaes inscripções votivas, honorificas e funerarias. Hubner, o celebre epigraphista allemão ha pouco fallecido, apreciou-a no justo valor, colligindo nas suas obras de vasta erudição todos os elementos epigraphicos que o museu ministra. Destaca-se também a collecção de fibulas de bronze, os velhos alfinetes de segurança com que o Lusitano apertava o negro «sagem» de lã grosseira: as formas e as ornamentações são das mais originaes e artisticas que se teeem encontrado no paiz. E, como estes, variadissimos monumentos minusculos e interessantíssimos das civilisações antepassadas.

Devendo-se fundamentalmente esta bella obra sicentifica ao esforço intellectual e até aos sacrificios monetarios do capitão Lopo, folgamos em consignar aqui um publico testemunho de apreço ao benemérito creador de um dos mais proveitosos estabelecimento educativos do paiz»».

As linhas que ahi ficam transcriptas são para meditar no que respeita á iniciativa particular que no caso presente supplanta a obra dos nossos governos.

Assim todas as terras mais importantes do paiz, onde surge um benemérito da historia nacional, vão auxiliando os emprehendimentos que as illustram aos olhos de toda a gente culta.

Em Braga, no principal Convento Juridico da Provinda Tarraconense, nada se faz de proveito.

Ha talvez um século que se reclama a fundação d'um museu aqui, mas das vereações que se succedem apenas ha a registar «a boa vontade e um pequeno auxilio» da que foi presidida pelo snr. dr. Balthazar Aprigio!

Entregue a toda a serie de sacrificios temos, como nenhuma terra, um archeologo incansável, o snr. Albano Bellino, que, apesar da indifferença geral dos bracarenses, vae recolhendo no seu museu particular todos os monumentos mais valiosos de Braga, não podendo ainda assim, por falta de auxilio, completar a sua obra de preservação de tudo o que vae apparecendo e do mais que se conserva occulto em locaes bem conhecidos, bastando para estes o alvião.

Conimbriga, 24 (1985), 5-83 
Pede o snr. Albano Bellino urna casa apropriada para expor ao estudo dos sabios e ao exame do publico em geral, essa rica collecção, mas não surge quem o comprehenda, quem ame com fervor esta terra, livrando-a da vergonha que ha tanto pesa sobre os seus habitantes mais illustres»

Pois pena é que não se aproveite a boa vontade de um homem competente.

Comércio do Minho 15-10-1904

\section{Arckeologos portuguezes}

A Real Associação dos Archietectos e Archeologos Portuguezes, em sua ultima sessão, consignou na acta um voto de sentimento pela morte do seu socio correspondente snr. Albano Bellino, e admitiu como socios correspondentes n'esta cidade os rev. ${ }^{\text {mos }}$ conegos Gonçalo Joaquim Fernandes Vaz e José Martins Peixoto, e o snr. dr. Manuel Monteiro.

Comércio do Minho, 8-1-1907

\section{Espolio archeologico de Albano Belinno}

$\mathrm{Na}$ quarta-feira penúltima chegaram a Guimarães, indo d'esta cidade em oito carros de bois, alguns objectos de valor archeologico, os quaes faziam parte do museu que o saudoso Albano Bellino aqui possuia.

Pela exc. ma viuva do illustre extincto foram offerecidos ao museu da Sociedade Martins Sarmento, de Guimarães, onde se vae fundar uma secção á parte, intitulada Albano Bellino.

Comércio do Minho 14-2-1907

\section{Marcos miliarios}

Com os ultimos temporaes algumas arvores do formoso local das Carvalheiras foram derrubadas, levando estas na sua derrocada dois marcos miliarios.

A commissão municipal ordenou que os mesmos fossem novamente levantados, trabalho este que ficou concluido no ultimo sabbado.

Comércio do Minho, 22-1-1908

59. Architectos e archeologos

Assumiu a presidencia da delegação da Real Associação dos Architectos Civis e Archeologos Portuguezes em Braga o capião d'engenharia militar snr. d**. João Teixeira da Silva.

Comércio dc Minho, 4-12-1909 
60. Liga de Braga

O snr. dr. Francisco José de Faria, illustre presidente da «Liga de Defesa e Propaganda dos Interesses de Braga», ofñciou á camara municipal communicando-lhe a installação legal de aquella collectividade, com séde provisoria no edifício da Associação Commercial, enviando-lhe um exemplar do seu estatuto e offerecendo o seu auxilio á municipalidade.

A «Liga» está resolvida a concorrer para a fundação d'um museu archeologico no recinto das Carvalheiras, e tenciona apresentar á apreciação da camara o projecto d'um edificio n'aquelle local e com tal destino.

Para o projectado museu concedeu já o snr. ministro da guerra dous escudos de granito, existentes no quartel d'infantaria 8, que se suppõe terem pertencido á antiga frontaria da egreja do Populo e ao jazigo do fundador dos frades agostinhos.

Além d'isto, a «Liga de Braga» conta com valiosas offertas e com a dedicação dos apaixonados pela archeologia.

Oxalá o patriotico intuito encontre o applauso de todos para a sua realização.

Comércio do Minho, 13-1-1910

\section{Achado romano}

$\mathrm{Na}$ abertura de uma das vallas a que se anda a proceder para o abastecimento d'aguas da cidade, o alvião dos trabalhadores cortou um enorme pavimento romano, que se suppõe ser o lastro d'uma piscina grandiosa.

Deu pelo caso o nosso amigo José Teixeira, espirito intelligentemente curioso, que consagra uma culta dedicação ás coisás d'outr'ora.

Communicando-o ao nosso collaborador Manoel Monteiro este, por sua vez, foi ao local proceder ao devido exame e logo conseguiu do dr. Arthur Soares uma bateria de trabalhadores que, se o tempo o permitir, procederá ás devidas excavações para arrancar do seio da terra a inesperada reliquia do tempo do dominio romano.

No proximo numero daremos minuciosa noticia da grata occorrencia.

Propaganda, 21-2-1910

\section{Museu archeologico municipal}

A «Liga de Propaganda» acaba de receber o officio que abaixo publicamos. Sabemos que sem perda de tempo se vae dar principio aos trabalhos indicados pela Associação dos Archeologos por modo que ainda n'esta quadra seja feita a plantação e regulado o jardim do recinto das Carvalheiras. 
Ao mesmo tempo será dada disposição convenientes a alguns dos monumentos alli existentes e a outros que para aquelle local vão ser removidos.

Com enthusiasmo applaudimos esta patriótica iniciativa.

Ill. ${ }^{\text {mo }}$ e Ex. ${ }^{\text {mo }}$ Snr.

Auctorisado pelo Ex. ${ }^{m o}$ Snr. Presidente da Delegação da Associação dos Archeologos e Architectos Civis, n'esta cidade, cumpre-me participar a V. Ex. ${ }^{a}$ que se deliberou aproveitar o local das Carvalheiras para o projectado Muzeu Archeologico Bracharense, cuja ideia, absolutamente louvável, eu me abstenho de encarecer agora.

Ora sendo certo que o alludido sitio é, pela sua disposição e pela sua tradição, o mais naturalmente indicado para tal fim, carece contudo de ser por completo arborisado e de soffrer um ligeiro arranjo para que os objectos a expor se tornem visiveis ao publico sem esforço e com methodo e com logica.

Repellindo o arboricidio, como um crime que devia ser punido por lei, cumpre-me dizer a V. Ex. ${ }^{a}$ que é necessario poupar as velhas arvores existentes, ao lado das quaes se deve plantar o arvoredo novo, afim de completar o revestimento frondoso, que outr'ora deu nome ao ameno local e de que muitos dos nossos concidadão saudosamente se lembram.

O plantio, porém, tem de ser feito á orla dos futuros canteiros a organisar segundo o parecer que eu tenho a honra de submeter á apreciação de V. Ex. ${ }^{\text {a }}$ que se dignará acceita-lo ou não:

Um arruamento circuitante será feito em cada um dos dois planos destinados a guardar as antiguidades - as romanas e medievaes no inferior e as da Renascença em deante no superior.

Dentro d'esse arruado ou perimetro dividir-se-ha aquelle em quatro talhões, subordinados á obra de cantaria que ali se encontra e se não deve inutilisar.

O de cima, na parte direita, será cortado por duas ruas diagonaes formando quatro canteiros triangulares, e, na esquerda, estes serão semicirculares, com os diametros voltados para o exterior.

Munidas de bancos as alamedas e guarnecidas as paredes de grades, eis o remate indispensável para tornar o magnifico recinto n'um recanto delicioso pelo deleite panorámico que d'elle desfructa a retina e pela lição e pelo ensinamento a colher nas coisas do passado, que V. Ex. a pretende ali reunir com solicitude e carinho.

Braga, 19 de Fevereiro de 1910. Braga».

Ill. ${ }^{\text {mo }}$ e Ex. ${ }^{\text {mo }}$ Snr. Presidente da «Liga de Defeza e Propaganda de

Manuel Monteiro

Propaganda, 21-2-1910

Conimbriga, 24 (1985), 5-83 


\section{Museu municipal}

O snr. presidente da «Liga de Defeza e Propaganda de Braga», acaba acaba de receber da Delegação da Associação dos Architectos e Archeologos de esta cidade o officio que em seguida publicamos.

Sabemos que as indicações n'elle contidas vão ter rapida solução.

Ill. ${ }^{\text {mo e Ex. }}{ }^{\text {mo }}$ Snr. Presidente da «Liga de Propaganda»

Em additamento ao meu ultimo officio cumpre-me lembrar a V. Ex. ${ }^{a}$, que, nem só o recinto das Carvalheiras pode ser destinado ao Museu Archeologico.

E' absolutamente imprescindivel um edificio condigno, onde se arrecadem e ponham ao abrigo todos os objectos que não podem expor-se á acção do tempo.

N'esta conformidade e sabendo que não ha capitaes ou recursos para se erigir um edificio apropriado a tal fim, e sabendo muito melhor que a educação portugueza, alheia a interesses d'esta ordem, não origina rasgos beneméritos que nos auxiliem na consecução d'este dezideratum, propoz o Ex. ${ }^{\text {mo }}$ Snr. Presidente da Delegação da Associação dos Architectos e Archeologos d'esta cidade, na sua derradeira reunião, que se indicasse a V. Ex. ${ }^{\mathrm{a}}$ a ideia do arrendamento d'uma parte do rez do chão do palacete da familia S. Martinho, também sito nas Carvalheiras.

Provisoriamente se guardariam aqui todas as velhas reliquias já adquiridas e as que se venham a adquirir com o appello que V. Ex. ${ }^{a}$, conjuntamente connosco, se dignará fazer á generosidade e ao patriotismo dos cidadãos bracharenses.

Braga, 26-11-1910.

Ill. rao e Ex. ${ }^{\text {mo }}$ Sr. Presidente da «Liga de Propaganda».

MANOEL MONTEIRO

Propaganda, 28-2-1910

\section{Achado romano}

Ainda se não pôde proceder, por completo, á desobstrucção dos restos do mosaico enxergado na ruptura d'uma das vallas que se andam a aluir para a collocação dos canos destinados ao abastecimento d'aguas da cidade.

Já se recolheram alguns fragmentos de mosaico; outros faltam ainda.

Conforme o tempo o permitir assim se procederá com cuidado ao levantamento do que se acha soterrado e será descripto aqui, com minucia, logo que a exploração se termine. Consola affirmar que todos os espiritos cultos d'esta terra seguem com verdadeiro interesse os trabalhos de remoção do interessantíssimo achado.

Propaganda, 28-2-1910 


\section{Achado archeologico}

No largo de S. Thiago principiaram sabbado as escavações para pôr a descoberto um supposto pavimento de piscina romana, cujos indicios foram encontrados ao abrir urna valla para a canalisação das aguas.

Comércio do Minho, 1-3-1910

\section{Escavações}

Teem continuado conforme o tempo o permite, as escavações no largo do Collegio, onde appareceram suppostos restos d'uma piscina romana.

Ignora-se por emquanto do que se trata.

Cousa antiquissima, é; romana, que o digam os entendidos.

$\mathrm{O}$ que se vê é um trecho de pavimento formado por argamassa rija, parece que revestido de curioso azulejo, de que foram encontrados pedaços.

Ha mais uns canos evidentemente para agua, cujo lastro e capeamento é formado de magnificos tijolos, e as paredes lateraes de pedra.

Estes canos parece partirem d'aquelle pavimento, seguindo um d'elles a direcção do arco do Collegio.

Veremos o que mais descobre o alvião dos operarios, e iremos informando os nossos leitores.

Comércio do Minho, 5-3-1910

\section{Escavações}

Pouco se tem adeantado nas que se andam fazendo no largo do Collegio, a proposito d'uma supposta piscina romana.

Por emquanto, o que ha de mais notável são os canos de tijolo a que já nos referimos, e que nos parece não terem nada de romanos.

Mas os competentes dirão da sua justiça, e nós acataremos a sua respeitável opinião.

Comércio do Minho, 10-3-1910

\section{Sepultura romana}

Ao proceder-se á excavação para o plantio d'uma oliveira, no Campo de Portas, pertencente á familia S. Martinho e sito em S. Pedro de Maximinos, encontrou-se uma sepultura cavada em terreno salão e com os lados guarnecidos de largos tijolos romanos.

Participado o facto ao honrado e muito digno administrador da casa S. Martinho, o snr. João Vieira, fez-se gentilmente acompanhar de dois entendidos no assumpto, que effectivamente verificaram tratar-se d'um coval, sim- 
ples, revestido lateralmente de tijolo, sendo este, por signal, o meio usado na cobertura.

Um e outro revestimento cerámico achavam-se em bom estado de conservação. O seu comprimento era de $1,{ }^{\mathrm{m}} 70$, a sua profundidade de $0,{ }^{\mathrm{m}} 58$ e a sua maior largura de $0,{ }^{\mathrm{m}} 56$.

Pelo conspecto feito averiguou-se que a curiosa sepultura já havia sido violada e exhumada.

Propaganda, 14-3-1910

69. Sepultura romana

Diz-se que no campo de Portas, em S. Pedro de Maximinos, ao ser plantada uma arvore, foi encontrada uma sepultura guarnecida de tijolos romanos.

Comércio do Minho, 17-3-1910

\section{Archeologia e arte}

Foi segunda-feira publicado um decreto segundo o qual, para o effeito da defeza dos interesses artisticos e archeologicos, é dividido o paiz em tres circumscripções: a $1 .^{\text {a }}$ comprehendendo os districtos administrativos de Santarém, Portalegre, Lisboa, Evora, Beja, Faro e os das ilhas adjacentes; a 2.a , os de Aveiro, Coimbra, Vizeu, Leiria, Guarda, Castello Branco; e a 3..$^{\text {a }}$ os de Vianna do Castello, Braga, Porto, Villa Real e Bragança. A 1. ${ }^{\text {a }}$ terá como séde Lisboa; a 2. ${ }^{\text {, }}$ Coimbra; e a 3. a o Porto.

$\mathrm{Na}$ sede de cada uma das circumscripções funccionará, com attribuições consultivas e deliberativas, um conselho de arte e archeologia.

Comércio do Minho, 1-6-1911

\section{Achado archeologico}

Nas excavações a que se procede na extincta egreja dos Remedios, foi encontrado um «carneiro» e uma pedra com esta inscripção:

0SSA3BA-

CVLVM FVN-

DATORIS

NOSTRI

JACENT HIC.

Conimbriga, 24 (1985), 5-83 
O «carneiro» continha uma ossada humana fragmentada, que se suppõe seja a de D. Frei André de Torquemada, bispo titular de Dume e coadjuctor do arcebispo D. Manuel de Souza, e fundador do convento dos Remedios.

Comércio do Minho, 11-5-1912 e Ecos do Minho, 12-5-1912

\section{Bibliotheca e archivo}

O director da bilbiotheca publica d'esta cidade, snr. dr. Alberto Feio, voltou a conferenciar com o snr. ministro do interior, sobre a creação de um museu de arte e archeologia junto de aquelle estabelecimento. O snr. dr. Rodrigo Rodrigues ficou de levar ao parlamento uma proposta de lei sobre o assumpto. O snr. dr. Alberto Feio ainda tratou com o snr. ministro do interior da questão dos archivos da mitra de Braga.

Comércio do Minho, 22-5-1913

\section{Achado arqueológico}

Em frente ao número 64, no lado norte do largo da Senhor a Branca, quando se procedia à construção de um aqueduto encontrou-se à profundidade de 80 centímetros uma espécie de sepultura com bordas e tampas de tijolo com mais de 2 centímetros de espessura.

Comércio do Minho, 24-4-1913 e Ecos do Minho, 26-4-1913

\section{Apparecimento de catacumbas nos terrenos do antigo convento dos Bemedios}

No pavimento onde durante algumas centenas d'annos esteve erecto o templo do extincto convento dos Remedios, últimamente demolido, appareceram agora, a pequena profundidade, muitas sepulturas, todas com tampas de granito, vendo-se n'algumas inscripções e n'outras emblemas heráldicos, o que demonstra que as monjas n'ellas sepultadas deviam pertencer a familias nobres.

Essas sepulturas foram encontradas em virtude de estar a proceder-se á reforma do largo, pois se assim não fosse ali ficariam ignoradas.

Crescido numero de curiosos teem ido ao local para verem o pequeno cemiterio.

As sepulturas não foram descobertas após a demolição do templo, porque entre ellas e o soalho da egreja havia uma espessa camada de terra d'alguns centimetros, agora removida.

Comércio do Minho, 17-8-1913

Conimbriga, 24 (1985), 5-83 
75. Achado archeologico

Junto de um dos cafés da Arcada, onde se anda a proceder a obras, terreno que pertence á irmandade da Lapa, foi descoberta uma porta ogival, voltada ao nascente, tendo no cimo um brazão que estava encoberto com uma espessa camada de cal.

Esta porta, situada a poucos metros da torre de menagem, parece que dava para ella entrada.

Comércio do Minho, 23-8-1913 e O Imparcial, 23-8-1913

76. As sepultura dos Remedios

Tem-se encontrado, nas obras de demolição do velho convento, varias inscripções, armas e brazões, que os entendidos em archeologia se aprestam a estudar.

Ecos do Minho, 18-9-1913

77. Achado de alguns objectos interessantes de armaria c indumentaria

Continuam sendo removidas para o cemiterio publico as ossadas e objectos que vão sendo encontrados nas sepulturas da demolida egreja dos Remedios, d'esta cidade.

Ha dias appareceu um espadim com copos de prata lavrada, um par de esporins e uma peça de um capacete.

N'outro dia foi encontrada uma mitra, que se suppõe pertencer a D. Fr. André de Torquemáda, fundador da egreja e convento dos Remedios.

Comércio do Minho, 23-9-1913 e Ecos do Minho, 25-9-1913

\section{Achado arqueológico}

$\mathrm{Na}$ demolição de uma parede da Quinta do Cravinho, à rua dos Marchantes, apareceu uma pequena porção de moedas romanas de cobre. O senhor doutor Arnaldo Machado, dono da referida quinta, ofereceu as moedas encontradas à Biblioteca Pública de Braga para enriquecer a respectiva colecção numismática.

O Imparcial, 6-12-1913 
79. Moedas romanas

No quintal da residencia do sr. Adriano Aragão, na rúa Gabriel Pereira de Castro, appareceram diversas moedas romanas do tempo do imperador Constantino, perfeitamente conservadas. Estavam encerradas n'um vaso, e foram encontradas quando se procedia a uma escavação.

Ecos do Minho, 3-4-1914

80. Poisson d'avril

Não passou de partida do primeiro de abril, a noticia de ter sido encontrado, no quintal do predio habitado pelo snr. Adriano Aragão, á rúa de Gabriel Pereira de Castro, um vaso cheio de moedas romanas.

Algumas pessoas chegaram a ir ao engano, a casa do snr. Aragão, para verem as famosas moedas do imperador Constantino.

Comércio do Minho, 4-4-1914

\section{Conselho de arte e archeologia}

Foi publicada uma portaria confirmando a eleição dos snrs. dr. Manuel Monteiro e Antonio Albino Marques de Azevedo para vogaes do conselho de arte e archeologia da $3 .{ }^{a}$ circumscripção.

Comércio do Minho, 8-12-1914

\section{Museu archeologico}

A direcção da delegação em Braga da Sociedade de Propaganda de Portugal vai pedir ao governo a cedência de parte do edifício em construcção para repartições publicas no largo do Barão de S. Martinho, afim de instalar ali um museu archeologico.

Comércio do Minho, 10-3-1917

\section{Museu archeologico}

Vae ser levantada a planta da cerca do antigo paço archiepiscopal, a fim de ser adaptada ao museu que se projecta crear n'esta cidade. 


\section{Museu e biliotheca}

Foram assignados decretos creando um museu de archeologia em Braga, que será installado no antigo paço archiepiscopal, onde ficará também a bibliotheca publica.

Para este fim será restaurada a parte do paço archiepiscopal voltada para a praça Municipal.

Esta importante noticia foi telephonicamente transmittida sexta-feira, pelo snr. presidente da republica, ao snr. governador civil d'este districto, e telegraphicamente, pelo snr. ministro da instrucção, ao snr. dr. Alberto Feio, que n'esse dia regressára de Lisboa onde fora tratar d'este assumpto e d'outros que se prendem com a futura remodelação dos serviços das bibliothecas e archivos. de Souza.

Ao museu archeologico de Braga será dado o nome de D. Diogo

Ao ministro da instrucção foram dirigidos telegrammas de agradecimento da junta geral d'este districto, camara municipal d'este concelho, delegação da Sociedade Propaganda de Portugal, Atheneu Commercial, Associação Commercial e commissão que promoveu a creação do museu.

Pela nossa parte congratulamo-nos sinceramente por mais este melhoramento concedido a Braga.

Comércio do Minho, 31-3-1918

85. Sem titulo

Ontem e onteontem foram transportadas em carretas para o Museu Dom Diogo de Sousa, desta cidade, os miliários romanos existentes há muito, no Horto Municipal, ás Carvalheiras.

Diário do Minho, 18-1-1925

\section{Importantíssima descoberta na rua de S. Vicente}

Ontem, pelas 9 horas da noite, quando os ouvintes do sr. Dr. Fontes saiam da igreja de S. Vicente, depararam na rua com uma multidão de rapazes, em delirante algazarra, como em arraial quente de festa.

Os jornaleiros da Câmara teem andado a fazer escavações na rua Cândido Reis, Largo dos Penedos e rua de S. Vicente, para substituir a tubagem subterrânea.

Um garotelho da rua de S. Vicente, da janela da casa de seus pais, lobrigara no fôsso, qualquer coisa reberberando, coruscando em um deslumbramento, á luz das lâmpadas eléctricas. 
Desceu pressuroso, em manifestação irreprimível de alegia, alvoroçado como quem vai recolher um tezouro.

Das casas próximas, dentro em pouco, irrompeu a garotada, curiosamente atraída pelos gritos estrepitosos do visinho.

Os pequenos, escarvando com as mãos no ponto irradiante, descobriam um depoito de moedas de oiro em avultado número - algumas que trazem legendas constantinianas, sendo, portanto, da mais remota idade, - nada mais, nada menos que do IV século da nossa era.

Algumas peças são encaracterísticas, parece que de metais diversos.

A Câmara pensa em organisar um museu de numismática, em memória e para guardar a preciosidade, que os senhores Padre Aguiar P»arreiros e Dr. Alberto Feio, afirmam ter importância apreciabilíssima, pois as legendas vão dar que fazer aos arqueólogos e, possivelmente, causar uma revolução histórica.

Diário do Minho, 20-3-1928

\section{Um Sarcófago romano-cristão — como apareceu}

Em diversas dependências da Sé de Braga, próximas do claustro, alguns túmulos antigos se divisam, inepígrafos todos, que aí foram arrumados por ocasião das obras de D. Rodrigo de Moura Teles (1707-1728) e depois. Um, todavia, me chamou particularmente a atenção, a pesar-de encontrar-se quási sumido no meio de materiais vários de construção, acantonado no esconso da escada nobre que dá para a Casa Capitular e Tesoiro de Arte Sacra.

Como está de ver, o deplorável a que, desde longa data, o reduziu o uso extranho de receptáculo para a queima da cal e a penumbra quási fechada do recinto a custo permitia lobrigar, através da crosta adensada que o envolvia, uma ornamentação indecisa, nas testeiras e uma das faces; que a matéria prima, essa, não tardou a denunciar-se mármore rijo, levemente rosado.

Não me sendo possível proceder desde logo à indispensável limpeza, que me consentisse estudá-lo, aguardei para mais tarde o convinhável ensejo.

Prestes, no entanto, mo forneceu a decisão magnifica do Cabido em reunir, no terraço contiguo ao Tesoiro, as pedras de valor arqueológico e artístico dispersas naquele meio e noutros, ainda, que podesse angariar, de forma a constituir mais uma secção interessante daquela, já hoje iniciada e em marcha auspiciosa.

Nos fins de Março último foi, pois, o túmulo removido, a titulo provisório, para uma das alas do claustro, onde mais facilmente podia tornar-se conhecido e servir de incentivo apetitoso a quantos as velhas pedras comovem. Oito meses, porém, já decorreram que farte, para que o belo sarcófago haja de prestar-se por mais tempo, ali, às exigências dos decalques, fotografias e medidas - o que, aliás, não o impede de continuar, como desde então, a instrutiva incumbência no lugar que lhe está destinado. 
Posto isto, vem agora de molde aquilatar do valor déste sarcófago, o qual, tendo incontestável direito a uma bem documentada monografia, apenas conseguiu, até ao presente, sugerir a pobresa mesquinha desta singela notícia.

Tenho para mim que o referido túmulo é romano-cristão, possivelmente do século iv.

A cuva, talhada em paralelograma, à moda romana, apresenta em minguado relêvo, numa das testeiras, o primitivo monograma de Cristo composto das letras gregas $\mathrm{X}$ e $\mathrm{P}$, que são as duas primeiras do nome de XPISTOS, acompanhado da primeira e última letra do alfabeto grego A $\mathrm{M}$ (alfa e omega), vendo-se nos intervalos disseminadas pequenas rosas de seis pétalas - tudo a preencher o amplo vasio de uma coroa, que semelha a de loiros. Nas juntas ao fundo, os ângulos adornam-se de nervadas folhas de parcimonioso recorte.

$\mathrm{Na}$ testeira oposta ostenta-se uma ânfora romana cercada de rosas, em tudo iguais e na mesma ordenança das outras.

Identicamente romana é a ornamentação de uma das faces, enquadrada em vergônteas de regular simetria, em que, à parte o monograma e a coroa, se repetem os motivos anteriores. Nesta face, todavia o adorno, à conta da imperdoável rasura de um pico vandálico, pouco mais do que vestígios conserva.

Por desdita, falta ao sarcófago a tampa, em cujo rebordo, de topo, levaria, quiçá, uma inscripção; que assim era, de ordinário, o sistema desta classe de sarcófagos limitados aos símbolos e decoração simplesmente ornamental.

Que túmulo é cristão manifesta-o evidentemente o monograma que assinala; romano, indica-o a rigor a identidade da forma e do estilo com os de Roma, no século iv, os quais, por sua vez, revelam, nesta centúria, um descuido acentuado de técnica, tal como neste da Sé de Braga. E' que a influência de Roma na indústria dos sarcófagos do Ocidente foi muito real.

E' o sábio H. Qeclercq quem o diz (Manuel d'Archeologie Chrétienne, Tom. II, pag. 304): «Durante todo o século iv, Roma forneceu de sarcófagos, de modelos ou de escultores a Itália, a Gália e os países ribeirinhos do Mediterrâneo. A exportação dos sarcófagos por terra e por mar ocasionou a fundação de sucursais longinquas, onde, pouco depois, a arte romana imperava a distâncias consideráveis do seu centro»».

\section{G. Manuel de Aguiar Barreiros}

Diário do Minho, 6-12-1932

\section{Uma Citánia no Monte das Caldas}

A convite dum velho amigo subimos ante-ontem o Monte das Caldas, elevação penhascosa que a cinco quilómetros a leste de Braga dominam as extensas veigas de Sequeira e Cabreiros e donde deslumbrantes panoramas se descobrem até muitas léguas para qualquer dos pontos cardiais. 
Sabíamos, os da campanha, que manhã cêdo o sr. dr. Carlos Teixeira com alguns cavadores para ali se tinha dirgido no intuito de proceder a escavações no ponto mais elevado da montanha, porque uma visita há tempos ali efectuada lhe deixara a certeza da existência duma antiga povoação no género das já nossas conhecidas do Sabroso ou de Briteiros.

Não era pois sem uma certa emoção que monte acima procurávamos os difíceis atalhos por onde possivelmente buscavam sua morada os luzitanos de tam aguerrida fama, ou outros povos mais antigos ainda que por lá curtissem as amargas penas duma vida acidentada e difícil.

Para dar alento à ascensão, os companheiros bem dispostos disparavam frases de espirito e inofensivos remoques ao passo vagaroso dos retardatários.

A frente, saltitando alegres, o Dr. J. Louro e o Dr. M. Braga da Cruz na ânsia de atingirem depressa a cumeada e surpreenderem o investiagdor a contas com . moiíms encantadasou calcurriando a passo lento velhos corredores de secretas passagens.

Atrás, devagar, saboreando a doçura duma tarde amena após tantos dias de frio polar, os Drs. Prieto e Olindo Pelaio, atentos às evoluções dos caminheiros da frente.

Tendo desafiado as atenções do vulgo que nos destacou alguns miúdos para nos servirem de guias pelas melhores veredas, chegamos ao cimo da montanha e logo de entrada nos demos por recompensados da penosa marcha.

A nossos olhos apareciam, como por encanto, os alicerces das antigas habições de povos cuja fama se perdeu.

O trabalho de investigação fora coroado de explendido êxito e o $\mathrm{sr} \mathrm{dr}$. Carlos Teixeira rejubilava ao deparar com as casinhas circulares ou rectangulares, ou ainda rectangulares de cantos arredondados, já suas conhecidas de outros castros que têm sido cuidadosamente estudados.

Contornamos o vasto planalto terreno de mato e pinheiros, pertença actual do abastado proprietário sr. Ferreira Dias, também regedor de Sequeira e que obsequiosa e gentilmente nos acompanhou.

Este domínio coroa o Monte das Caldas e em tôda a volta pudemos ver as linhas de defeza da antiquíssima cidade.

Em alguns pontos as pedras da muralha afloram do terreno alinhado, deixando antever a possibilidade da existência de largos e altos muros soterrados. Aqui e além junto de pedreiras que foram exploradas para extracção do lindo granito da região, vêem-se alguns metros da cintura exterior que cercava o povo. As pequenas escavações realizadas deixaram a descoberto o solo das moradias, de barro calcado, à mistura com cinzas. Objectos de uso ou de adorno não apareceram ,senão os restos de ânforas ou quaisquer outros artefactos em barro modelado à mão.

E' possível, todavia, que apareçam inscrições ou utensilios que permitam uma reconstituição histórica, se alguém com dinheiro e boa vontade determinar a fazer mais profundas investigações. 
Foi desta arte que Martins Sarmento procedeu em Briteiros, no Sabroso e no Monte Redondo.

Verifica-se que as elevações que circundam a cidade de Braga foram todas noutros tempos povoadas e que magníficas recontituições da pre-história se podem fazer neste rincão abençoado do Minho, onde vivemos agradecidos a Deus que nos deu por morada tam encantador paraíso e onde viveram enlevados no mesmo bucolismo e sentimento os celtas, os lígures e os luzitanos. Que não esmoreça no prosseguimento dos seus estudos e averiguações cientificas o nosso amigo, sr. dr. Carlos Teixeira, são os votos que faz o cronista do passeio de quinta-feira passada.

Diário do Minho, 2-2-1935

89. Foram encontradas no Monte de Castro as ruinas duma cidade pré-romana em tudo idêntica ao Castro de Sabroso - As investigações teem sido efectuadas pelo sr. dr. Carlos Teixeira que hoje explica aos leitores do "Correio do Minho» o que ela vale e representa

Há já bastante tempo que sabiamos se andava a fazer importantes escavações no Monte de Castro. Sabíamos, ainda, que as orientava o sr. dr. Carlos Teixeira, discipulo e continuador do Professor Mendes Correia nos estudos pré-históricos. No entanto, não nos atreviamos a trazer o assunto para o jornal receosos de prejudicar, com uma notícia inconveniente, os trabalhos do novo mas já talentoso investigador.

Circunstancias fortuitas demoveram-nos, agora, dessa resolução, expontaneamente adoptada.

Conhecedora das escavações, que já se encontravam adiantadas, a gente das proximidades nomeadamente a da Avenida Artur Soares - mudou-lhes o objectivo e o sentido, afirmando, alvoraçada, que se havia descoberto no referido monte um tesoiro precioso. Estabeleceu-se o «levante» surgindo com êle, a conveniencia de se esclarecer a verdade dos factos.

Chegava, assim, mansamente, a hora do jornalista.

$\mathrm{O}$ sr. dr. Carlos Teixeira reside, actualmente, no Internato Liceal onde é professor.

E' uma pessoa de extraordinário merecimento, embora use uma vincada modestia e o maior desprendimento por tudo que signifique ambição ou prazer material. A sua via de estudante decorreu num ambiente de estudo e de reflexão interior. Durante ela revelou-se um espírito penetrante e profundo e um apaixonado das sciências antropológicas, onde se havia de distinguir merecidamente.

E' esta a pessoa, pois, que vai dizer aos leitores do «Correio do Minho» no Monte de Castro.

$\mathrm{O}$ sr. dr. Carlos Teixeira recebe o jornalista na pequena sala de visitas do Internato - uma sala modesta, é certo, mas onde ha beleza, harmonia e 
higiene. Urna sala duma verdadeira casa de educação. Trocados os breves cumprimentos protocolares diligenciamos expor, com o necessario cuidado com nitido receo - os fins que ali nos levavam. Referimo-nos aos estudos feitos e á necessidade, que nos parecia haver, de ensinar o publico, de lhe explicar a natureza do tesoiro...

O nosso entrevistado - porque agora já o era - sorriu, amavelmente, e concordou. - Pois sim. Falemos, então, dos Castros e das minhas investigações.

Houve, seguidamente, uma pequena pausa - para alinhar ideias, para fixar juizos. Depois, indo direito ao nosso objectivo, principiou:

O que eram os Castros

Os castros (também chamados crastos, citanias, cividades, castelos, crastelos, etc.) eram povoações primitivas, situadas geralmente no alto de montes, limitadas por fossos e contornadas por linhas, quási sempre duplas ou triplas de grossas muralhas, onde se abrigavam os nossos antepassados de há mais de 2000 anos. Nessas épocas recuadas o estado de guerra era constante. Compreende-se pois a necessidade de tais fortificações que, pela sua situação em lugares quási inacessiveis, se tornavam facilmente defensáveis.

No espaço limitado pelas muralhas e em planos sucessivos erguiam-se, feitas de pedra solta, as casas, de pequenas dimensões, a maior parte das vezes irregularmente dispostas e, nos castros do Norte de Portugal e Galiza, de forma geralmente circular. A sua cobertura era feita com barro ou colmo e só mais tarde, após a invasão romana, foi usada a telha. O pavimento era feito com barro batido, sem cosedura e algumas vezes construido com pedra ou tijolo. Uma estaca colocada a meio da casa, sobre uma pedra, servia de apoio ao tecto. A porta era acanhada e janelas parece que raras vezes existiam.

Os habitantes, que nós costumamos designar por Lusitanos, eram pastores, fabricavam louça e utensílios grosseiros de barro, usavam armas e adornos de ferro e de cobre, etc..

O pão que comiam era feito, segundo hoje se crê, com landres de carvalho torradas e moídas. A caça, o leite e a carne dos seus rebanhos constituiam a sua alimentação principal.

Vestiam, como nos mostram várias estátuas de pedra representando guerreiros, uma espécie de túnica, feita de lã ou pêlo de cabra, que lhes descia quási até ao joelho e a que os Romanos chamavam sagum. Tinham por armas um punhal curto e usavam escudo redondo.

Estrabão descreve êstes povos como sendo robustos e fortes, de cabelos compridos e dados a dansas e jogos de agilidade e destreza.

Conimbriga, 24 (1985), 5-83 
Tinham deuses próprios que adoravam, mas após a subjugação romana adoptaram facilmente os deuses dos invasores, muitos dos quais, mais tarde, foram, digamos assim, transformados em santos cristãos.

A entrada para os castros era feita por portas abertas na muralha mas em muitos déles esta é contínua e então a passagem fazia-se através de pranchões de madeira fácilmente removíveis á noite e em ocasiões de perigo.

A maioria dos castros tem uma origem pré-histórica como o provam objectos achados em muitos déles.

$\mathrm{O}$ sr. dr. Carlos Teixeira expõe com impressionante facilidade a sua lição...

E nós, interessados em ouvir e registar, não nos atrevemos a interrompê-lo...

Este parêntesis faz-se aproveitando uma ligeira pausa, mas logo o ilustre professor continua:

- Os nossos montes estão em grande numero coroados pelas ruinas de castros e citanias. A abundancia destas povoações castregas surpreendeu deveras Virchow quando, durante o congresso de Antropologia de 1880, percorreu as nossas províncias do Norte.

E o povo que não lhes esqueceu o nome, pois a maior parte são-nos revelados pela toponimia, cobria-os, no entanto, de ingénuas e doiradas lendas. Não há ruina destes onde a gente inculta (e a culta até) não veja sitio de tezoiros ignorados e da qual não conte poéticas históricas de moiras e encantos. E no seu pensar tudo é trabalho de mouros...

Sendo a dominação árabe na Peninsula muitíssimo mais moderna não é de admirar que perdure mais viva na alma popular.

Quanto os povos castrejos eram aguerridos e ardilosos provam-nos as lutas que os Romanos tiveram de sustentar para os subjugar. Mas, pouco a pouco, foram adoptando os costumes dos invasores, abandonando os seus redutos montanhosos para se fixarem no vale.

Os restos encontrados nas ruinas dos castros são geralmente diminutos pois o seu abandono foi lento; são constituidos mais geralmente por fragmentos de cerámica, fibula, mós, esculturas várias, etc.. Nos romanisados encontram-se ainda abundantemente telhas de rebordo — tegullae e imbrex moedas de imperadores romanos, inscrições, etc..

Ms investigações no Monte de Castro

Uma pausa longa leva-nos a concluir que o sr. dr. Carlos Teixeira acabou de leccionar...

Decidimo-nos, por isso, a lançar uma interrogação:

- Mas porque despertou, o Monte do Castro, o interesse destas pesquizas?

- Levado pela curiosidade e pela indicação toponímica visitei um dia o Monte de Castro, quási certo de não achar vestígios já dos seus remotos 
habitantes, pois dada a sua proximidade da cidade, era de supor que estivessem destruídos.

Enganei-me. Logo no primeiro dia encontrei vários fragmentos de ceramica manual com ornamentação incisa analoga á de fragmentos encontrados em Sabroso que eu conhecia do museu de Martins Sarmento, e descobri mesmo uma pequena parte da parede de uma casa.

- Perante tão animadores resultados?...

- Resolvi proceder a pesquisas mais aturadas, que não conclui ainda, durante as quais encontrei fragmentos de cerámica manual, alguns com ornamentações lindíssimas, umas incisas outras estampadas, conoides, isto é, pequenos pesos de barro pergurados que serviam talvez como volantes de fuso, polidores, uma moeda romana de Constancio, etc.

Entre as ornamentações ceramologicas mais interessantes figuram os chamados palmipedes estilisados, os escudetes carregados de besantes, os circulos concentricos, os arcos em forma de ferradura, etc. característicamente da idade do ferro.

Alguns fragmentos pertenceram a vasos enormes, de grandes bordos horisontais e outros mostram a existência de azas interiores analogamente aos encontrados noutros castros.

- Mas falaram-nos de uns alicerces...

- Sim. Puz a descoberto os alicerces de uma casa circular que não sei que vándalos destruíram já...

— Encontrou alguns vestígios de muralha?

- Não. Da muralha nada resta já mas pode desenhar-se aproximadamente a linha que seguiria á vista do fosso cujos vestígios ainda existem.

— Tinha conhecimento de outros achados no Monte de Castro?

- Guardo em meu poder, encontrados ali, uma parte de uma fibula de cobre e um machado de pedra polida (fibrolite) partido que me concedeu para estudo o Senhor Doutor Oliveira Machado. E o P.e Sena Freitas diz algures que possuia varias moedas romanas também ali achadas.

- Então já leu referências ao Monte de Castro?...

- Já. A citação mais antiga do Monte de Castro é feita em documentos de 840 e 905 sendo designado por «Castrum Maximum».

Em conclusão: trata-se dum castro pré-romano, pois não há vestigio algum de romanisação (a moeda encontrada estava situada superficialmente) bastante típico, com afinidades marcadas com outros castros entre os quais o de Sabroso.

- Vai tornar conhecidas estas investigações?

- Com os elementos que já tenho e com outros que obtenha em futuras pesquisas, não só do Monte de Castro mas doutros castros próximos, estou elaborando um pequeno estudo, que apresentarei á Sociedade Portugueza de Antropologia e Etnologia, talvez em Março.

Pena é que Braga não possua um museu de arqueologia pré-histórica onde se guardassem todas estas reliquias dos nossos primitivos antepassados, subtraindo-se á acção devastadora e selvagem de supersticiosos e ignorantes. 
Caía a tarde quando deixamos a pequena saleta do Internato onde o sr. dr. Carlos Teixeira nos acolhera.

O que ouvimos do distinto investigador - e que aí fica satisfazia plenamente a nossa curiosidade. E deve também satisfazer a do leitor que se nào tenha deslumbrado com a possibilidade da descoberta de tesoiros... onde só existe a afirmação duma época e dos seus costumes.

Comércio do Minho, 24-1-1935

90. Achado arqueológico — Apareceu perto da Sé um mosaico romano

Determinou ontem o Mestre Geral das obras camarárias que uma brigada dos trabalhadores que dirige, procedesse, na rua dos Mártires da Republica, à abertura de uma vala de ligação com os canos de aguas pluviais para estabelecimento de uma escoante ao enxurro que, em ocasião de chuvas ali toma notáveis proporções.

Prosseguindo no trabalho, vieram os operarios municipais a pôr a descoberto, pelas 10 horas da manhã, qualquer coisa que lhes despertou a atenção, obra de arte que não podiam avaliar, mas cuja importância logo entreviram. Suspendendo imediatamente os trabalhos, com um criterio superior ao que seria de exigir em tão modestos funcionarios, foram procurar o seu chefe que por sua vez reclamou a intervenção do senhor dr. Alberto Feio, director do Museu Municipal.

Comparecendo ali, o ilustre especialista verificou a descoberta de um mosaico romano, de vario colorido e desenho perfeito, de bom gosto artístico, dando instruções para que não sofresse qualquer estrago.

Vão tomar-se as medidas necessarias para fazer a exploração metódica do local onde está assente o mosaico, para se descobrir a sua extensão. Deve tratar-se de um atrium, certamente, e o prosseguimento da excavação dirá, possivelmente, a sua natureza e a época da construção a que pertencia.

Como primeira medida, rodeou-se a excavação já feita de uma vedação de arame, e como se aglomerasse o rapazio curioso, foi pedida à noite uma especial vigilância da policia, para que não sofra qualquer estrago o interessante achado arqueológico.

O local onde se encontrou, é poucos metros acima da Sé, em terreno pouco antes ocupado por edifícios da estreita rua de Santa Maria, de que são restos as casas do lado Nascente da actual rua dos Mártires da Republica e demolidas nos fins do século passado para alargamento dessa artéria. 
91. Achados arqueológicos com as obras de saneamento

Desde que as obras de saneamento entraram na zona da antiga cidade, têm sido vigiadas a-fim-de recolher todos os elementos arqueológicos postos a descoberto.

Na rua D. Paio Mendes surgiu um pano da muralha romana, na extensão de 9 metros, o que permitiu marcar com exactidão o extremo Norte da urbs, além de moedas, restos de colunas, cerâmicas, etc..

Nas ruas adjacentes à Sé também as excavações puseram a descoberto um lindo capitel corintio, em granito, bases de colunas, mós manuais, cerámica, etc..

Diário do Minho, 23-6-1937

\section{Achados arqueológicos}

No decurso das obras de Saneamento têm aparecido numerosas peças arqueológicas a que por vezes fizemos já referência.

E decerto que outras preciosidades terão passado despercebidos, como outras muito interessantes apareceriam se fosse possível fazer uma exploração metódica no subsolo da cidade, especialmente em certas zonas.

Registamos últimamente o aparecimento de numerosa cerâmica, romana, e em bom estado de conservação, bem como algumas moedas, na rua dos Granjinhos - (toda essa vertente do Este é riquíssima). Entre essas peças de cerâmica apareceram algumas lâmpadas verdadeiramente notáveis.

Ontem quando se abria a trincheira na rua da Cruz de Pedra foi descoberto um cipo com inscrição muito nitida. E' dos exemplares mais perfeitos dêste género que conhecemos. A legenda é a seguinte:

\section{TINTA}

MI. BO

BO AE

NI.F.A.Y.

A pedra mede 30 por 70 centimetros e as letras tem 6 centimetros de altura. Foi transportada para a Câmara donde seguirá para o Museu.

Diário do Minho, 9-7-1937

93. Urge riscar a Fonte do Idolo, do Guia do Turismo...

O caso merecia comentário apropriado, mas basta contá-lo para que quem de direito veja como o nome de Braga é diminuido aos olhos das pessoas que nos visitam e que teem de retirar enojadas sem poderem apreciar um

Conimbriga, 24 (1985), 5-83 
monumento nacional que o Guia do Turismo insere como pré-romano, coisa raríssima na Peninsula.

Referimo-nos, como os nossos leitores já adivinharam, à Fonte do ídolo, existente na rua do Raio, com uma taberna ao pé, onde jogadores do «fito», de gargantas avinhadas, proferem, durante a tarde, os mais obscenos palavrões.

Ontem, duas senhoras de nacionalidade suiça, acompanhadas de um cavalheiro de Lisboa, munidas do guia turístico da cidade, visitaram diversos monumentos e, atraídas pela raridade da Fonte do ídolo, dirigiram-se para ali, na esperança de apreciarem coisa nunca vista.

Porém, quando chegavam junto do monumento, um espectáculo estranho fê-las retirar envergonhadas: dois matulões, de calças arreadas, estavam a transformar aquilo em gabinete sanitário...

Escusado será dizer que o quadro, completado com a imundície do local e com as palavras soeses dos jogadores de patela, estava completo e não precisava de qualquer pincelada mais para afugentar os visitantes, sobretudo quando se trata de senhoras.

Ora isto, com se conclue, não está certo e representa uma vergonha para qualquer terra civilizada.

Se não há meio de evitar semelhantes escândalos, ao menos risque-se do Guia do Turismo a Fonte do Idolo e o nome da terra não mais será diminuido perante estranhos.

Assim é que não pode ser.

Diário do Minho, 15-1-1948

\section{Importantes investigações arqueológicas na Santa Marta da Falperra}

$\mathrm{Na}$ Santa Marta da Falperra estão a decorrer importantes escavações promovidas pela Câmara Municipal e executadas sob a orientação do conhecido e ilustre arqueólogo dr. Russel Cortez, bolseiro do Instituto para a Alta Cultura e professor no Porto.

As observações estão a ser feitas no Oppidum situado na plataforma inferior à Capela de Santa Marta das Cortiças e teem sido registados os melhores sucessos nos trabalhos já levados a cabo.

Removidas as primeiras terras, logo afloraram à superfície restos de uma parede, de aparelho romano, com os silhares belamente trabalhados num granito que não é local.

Esperamos que com o prosseguimento destes trabalhos novos restos arquitecturais surjam de forma a transformar o monte de Santa Marta numa ruina arqueológica de interesse nacional.

Mais uma atracção turística e monumental a incluir obrigatoriamente no circuito turístico da Falperra.

O sr. Dr. Russel Cortez tem dirigido os trabalhos em colaboração com o ilustre escritor e arqueólogo bracarense P.e Arlindo Ribeiro da Cunha, 
que desde há muito dispensa à historia e achados arqueológicos da Santa Marta a melhor atenção e que tem feito algumas das suas comunicações através do «Correio do Minho».

Correio do Minho, 23-5-1953

95. A região de Braga é habitada há 30.000 anos!... - Novas revelações das investigações arqueológicas levadas a efeito pela Câmara Municipal

Em aditamento às notícias que temos dado e em vista de trazer os nossos leitores informados dos resultados já obtidos e quebrando talvez a confidência duma conversa despretenciosa com o sr. dr. Russel Cortez vamos sumariar o que este ilustre arqueólogo, que ora vem dirigindo as investigações arqueológicas da região de Braga, nos confidenciou.

Entre outros pormenores soubemos que o testemunho da ocupação humana da região bracarense pode afirmar-se remotíssima, pois num dos taludes da nova estrada marginal o sr. dr. Russel Cortez localizou uma estação do Paelolítico inferior, do tempo em que o homem se servia de instrumentos de pedra lascada - ha mais de 30000 anos.

$\mathrm{O}$ sr. dr. Sérgio Pinto, vereador do pelouro de Cultura mostrou-nos um dos instrumentos achevienses, recolhidos por aquele arqueólogo, esclarecendo-nos que o sr dr. Russel Cortez, Bolseiro do Instituto de Alta Cultura, no Centro de Estudos de Etimologia Peninsular da Universidade do Porto, não foi nesta época a Paris, à reunião da Comissão Internacional de Ciências Históricas, de que é membro, só para poder acompanhar de mais perto os trabalhos em curso, que sob proposta do pelouro de Cultura, a nossa Câmara vem financiando, correspondendo ao entusiasmo do seu desvelado Presidente e demais vereação.

Sobre o opido de Santa Marta notamos um certo alvoroço, nas palavras do sr. dr. Russell Cortez, quando nos disse parecer-lhe terem surgido restos de parede de um edifício de planta basilical, nas escavações que ali, de colaboração com o Rev. ${ }^{\circ}$ P.e Arlindo Cunha, vem dirigindo. Mais nos segredou que espera poder atribuir os vestígios achados a uma basílica cristã, pois a sua planta, orientação e ténica construtiva é mui semelhante à basílica de Rolle que o mesmo antropólogo visitou na Jugoslávia.

Disse-nos, por último que o Rev. ${ }^{\circ}$ P.e Arlindo Cunha tem sido um admirável companheiro de trabalho, de tenaz assiduidade na presente campanha.

Esperamos que a inconfidência seja perdoada, mas o segredo jornalístico só pode guardar-se onde começa o interesse dos nossos leitores.

Correio do Minho, 7-7-1953

Conimbriga, 24 (1985), 5-83 


\section{Escavações em Santa Marta}

A convite do sr. Dr. Sérgio Pinto, vereador do Pelouro da Cultura da Câmara, fomos ontem ver as escavações que por conta da Câmara estão a ser levadas a cabo naquela estância, tão querida de todos os bracarenses.

Tendo como cicerones dois ilustrados arqueólogos, Srs. Cónego Arlindo Ribeiro da Cunha e Dr. Russell Cortez pudemos admirar a amplitude dos trabalhos já efectivados e as grandes esperanças que depositam no que ainda está para descobrir.

Na realidade, a zona a desbravar é enorme, metida numa larga cintura de muralhas e o que já vai descoberto permite formar os mais arrojados sonhos a propósito da riqueza arqueológica ali escondida.

Para já, esclarecemos o leitor de que acaba de ser feita uma descoberta que não vai deixar dormir os interessados, pelo inesperado do que pode revelar.

Com efeito, acaba de ser descoberto o traçado udm grande edifício que deve ter sido de interesse colectivo: religioso ou civil? Basílica ou qualquer outro edifício civil?

Pelas suas dimensões e pela actual disposição, inclinam-se a aceitar a hipótese de ser uma basílica e, a confirmar-se terá de ser revista, ao que julgam, parte do que até hoje sabemos da arqueologia cristã da península.

Esta leve referência aos trabalhos em curso pretende apenas chamar a atenção do leitor para um dos acontecimentos de mais interesse de hoje, nos domínios da arqueologia, e que virá a constituir, para Braga, motivo de legítimo orgulho, quando devidamente estudado e esclarecido.

Diário do Minho, 19-9-1954

\section{Protecçào às ruínas arqueológicas do Monte de Santa Marta}

$\mathrm{O}$ «Diário do Governo» publicou uma portaria que manda fixar, conforme planta anexa, o perimetro de protecção das ruinas arqueológicas do Monte de Santa Marta, freguesia de Nogueira, concelho de Braga, classificadas como imóveis de interesse público.

Correio do Minho, 28-12-1955

\section{Um monumento fontenário pagão ainda em uso na idade média}

Pois que me não foi possível levar o meu contributo ao Congresso Histórico de Portugal Medievo, venho por este meio dar conhecimento de mais um padrão da antiguidade existente no concelho de Braga, e em sítio 
que pode despertar o encanto dos turistas e a curiosidade de estudiosos. E' a «Fonte das Pardelhas«, em Palmeira.

Para os estudiosos bastaria dizer que está junto duma estação Arqueológica, que segundo o Senhor Dr. Russell Cortez tem objectos e eu possuo um raspador paleolítico e um «fóssil petrificados. Mas não ficam por aqui os elementos que despertam o interesse dos Arqueólogos.

Não vai há mais duma década que lá foi encontrado um grande «Dolium» cujo diámetro bocal é de perto de $0,70 \mathrm{~m}$. e a abetrura de bojo faz calcular a sua capacidade em mais de uma pipa. Apenas a parte superior foi extraída conservando-se em alguns bocados no Museu Pio XII. Nela se vêem várias inscrições como «RUTINI» e uma data do século xn. Daqui a ligação com o Congresso Medievo, por ainda ser utilizada na Idade Média, no nascimento de Portugal. O restante deve estar soterrado.

Até aqui ainda ninguém viu que esta poça ou fonte tivesse nada que a ligasse ou assemelhasse à «Fonte do Idolo». Mas nela se achou também muita coisa arqueológica. De cinza foram tonealadas que em 1948 o possuidor actual tirou, quando procedia à sua limpeza e afundamento! As brasas enchiam cestos! Isto numa poça abaixo do nivel do chão tres metros, junto da Povoação de Santo Estêvão das Pardelhas, de importância remotíssima, como refere o «Paroquial Suévico».

Ainda mais, uns bustos muito grosseiros, com orelhas mal cavacadas e de que se encontram as relíquias no já referido Museu.

Ao centro da poça, está um penedo com umas letras que a água impede de ler. Na base, quando se afunda, aparecem pedras trabalhadas. Convém dizer ainda não se atingiu o fundo nem extraiu o que possa dar a luz definitiva.

Era sem dúvida uma fonte pelo menos romana pois de lá veio uma Ara Romana que está no citado Museu. Essa fonte era monumento dos mortos ou consagrada a algum Deus, porque as brasas e as cinzas indicam cremação ou sacrifício. Tanto mais numa fonte... Umas tantas hipóteses que agradava esclarecer.

A povoação de Pardelhas serviu-se dessa fonte de abastecimento durante muitos séculos. Ai, para substituir o culto pagão se introduziu a devoção a Santo Estêvão Velho, como S. Victor o Velho. Em plena idade média teve seu explendor, ficava pero da ponte romana de Prado e por aí passava uma via de comunicação. Ali encontrei uma moeda rara de D. Manuel I, que não importa agora descrever.

Eis à laia de apontamentos umas breves notas o propósito do Congresso.

MAGALHẽeS SANTOS

Diário do Minho, 10-11-1959

Conimhriga, 24 (1985), 5-83 

99. Coroados de êxito os trabalhos arqueológicos realizados em Maximinos
e em Santa Marta das Cortiças

Foram coroados de êxito os trabalhos arqueológicos, últimamente realizados, promovidos pelo Pelouro da Cultura da Cámara Municipal de Braga. Dirigiram-nos os arqueológicos Rev. Dr. Pinho Brandão, professor de Arqueologia da Faculdade de Letras do Porto, e Prof. Rigaud de Sousa, do Conservatorio Regional de Braga, com a colaboração do Rev. Cónego Arlindo Ribeiro da Cunha. Participaram netses trabalhos alunos da Faculdade de Letras do Porto.

Na semana de 9 a 13 de Agosto fizeram-se sondagens na zona de Maximinos destinada a construções que se projectam para breve. Houve a preocupação de recolher, nesta zona, elementos de interesse para a historia antiga de Bracara Augusta. Dos vestigios ai encontrados durante as sondagens destacam-se: moedas romanas, uma pedra de anel, pedras ornamentais, fragmento de pulseira de vidro, fragmentoss de sigillata arretina, hispánica, Sud Galaica e clara, fragmentos de lucernas, fragmentos de cerámico de épocas diversas. Simultaneamente, os orientadores das sondagens tomaram conhecimento de objectos encontrados na mesma zona por particulares e em sua posse.

As escavações no Monte de Santa Marta decorreram de 16 a 30 de Agosto. Realizaram-se a W-NW da Capela numa pequena superfície junto da primeira ordem das muralhas.

Os trabalhos fizeram-se com o maior rigor científico. Os cortes feitos no local permitiram identificar fundamentalmente duas camadas sobrepostas perfeitamente distintas: a inferior, tardia, havendo entre as duas um considerável hiato de tempo.

A cerâmica da camada superior distribui-se por um período que não

parece anteceder o século $\mathrm{m}$ depois de Cristo e se prolonga até época tardia.

Além de vestígios de construções foram encontrados objectos de interesse. Entre eles: pequenas contas de colar, fragmentos de vidro, cerâmica ornamentada, sigillata, tardia, uma tessela de mosaico, um fragmento de acus crinalis, um pequeno machado polido. Recolheram-se, perto da zona explorada, duas mós oblongas.

As presentes escavações vieram lançar luz sobre os problemas arqueológicos relacionados com a estação arqueológica de Santa Marta, que futuras escavações melhor esclarecerão. Na parte final, o mau tempo impediu a boa marcha dos trabalhos.

Acompanharam com interesse as escavações o Dr. Egídio Guimarães, do Pelouro da Cultura da Câmara Municipal de Braga, promotor das escavações, e o Dr. Sérgio Pinto, da Faculdade de Letras do Porto.

Entre outros visitantesm estiveram nas escavações os distintos arqueólogos tenente-coronel Afonso do Paço e Prof. Santos Júnior. 
Os resultados das sondagens em Maximinos e das escavações do Monte de Santa Marta da Falperra serão apresentados, em estudo desenvolvido, ao $V$ Colóquio Portuense de Arqueologia, a realizai no Porto, no próximo mês de Novembro, pelos arqueólogos que orientaram os trabalhos Rev. Doutor Pinho Brandão e Prof. Rigaud de Sousa.

Correio do Mitiho, 31-8-1966

100. Os Trabalhos na Estação Arqueológica da Falperra

O Vereador do Pelouro da Cultura, Dr. Egídio Guimarães, apresentou na sessão de ontem a seguinte proposta:

«Ao apresentar, hoje, o relatório referente à campanha de trabalhos arqueológicos na estação arqueológica da Falperra (Santa Marta das Cortiças), a qual decorreu durante o mês de Agosto passado, de que é relator o Sr. Professor José João Rigaud de Sousa, trabalhos que tiveram assinalado êxito como se poderá ver por este relatório, é meu dever, como Vereador do Pelouro da Cultura deste Município, testemunhar o mais profundo reconhecimento a todos aqueles que trabalharam em estreita colaboração de modo a que esse êxito se concretizasse. É dever deste Pelouro, além disso, propôr, nesta Sessão da Ex. ${ }^{\text {ma }}$ Edilidade Bracarense, tal agradecimento público porque lhe coube a sorte de ser o instigador das novas investigações arqueológicas em curso e porque tem sido a Câmara Municipal de Braga a principal responsável pela sua efectivação.

Este agradecimento dirige-se, antes de tudo, a Junta Distrital de Braga representada pelo distinto Arqueólogo, Rev. do Senhor Cónego Arlindo Ribeiro da Cunha e ao Professor José João Rigaud de Sousa que foi o arqueólogo que assumiu a responsabilidade técnica do campo de trabalhos e cujos conhecimentos e métodos de investigação arqueológica mereceram dos sábios arqueólogos professor Santos Júnior, Catedrático da Faculdade de Ciências do Porto, e Tenente-Coronel Afonso do Paço, os mais altos e significativos elogios.

Ainda ao Professor Rigaud de Sousa desejo expressar um muito especial agradecimento pelo curso de iniciação ao estudo da arqueologia que regeu, graciosamente, desde Janeiro a Junho, no Conservatório Regional de Música, e que foi frequentado por grande número de estudantes dos últimos anos do Curso Liceal, os quais quase todos prestaram óptimos serviços em trabalhos de campo, durante as escavações arqueológicas em apreço.

Também quero dirigir o meu profundo reconhecimento ao Senhor Reitor do Seminário de Santiago, ao Superior do Seminário Carmelita da Falperra e às Madres Superioras do Instituto Missionário Espiritano, de Fraião e do Colégio Teresiano, desta cidade, pelo acolhimento que deram aos estudantes que tomaram parte nos trabalhos arqueológicos, estudantes quase todos de fora de Braga, sendo estrangeiros alguns deles, e que sacrificaram, aqui, o melhor mês das suas férias grandes, o mês de Agosto. 
Perante o valor da estação arqueológica da Falperra, aproveito a ocasião para propor, também, que seja feito um estudo no sentido de ser demarcada toda a sua zona e que esta seja considerada de interesse público.

Igualmente proponho que se mande proceder à reparação do acesso que conduz da Falperra ao alto da Santa Marta das Cortiças de modo a facilitar a ida até ao alto da montanha, de automóveis ligeiros, isto enquanto se não puder construir uma estrada como o merece o valor desta estação arqueológica, cujo estudo de exploração ainda se encontram, praticamente, no início.

Diário do Minho, 8-12-1967

\section{Vidros romanos de Brácara Augusta}

Só agora começa a tornar-se conhecida em pormenor a civilização romana em Braga. Hoje vamos ocupar-nos um pouco, explanando o tema dos vidros romanos em Brácara Augusta. Para isso temos diante de nós demonstrações de fragmentos encontrados em sepulturas romanas ou em estractos de terreno romanizado. Por isso o método científico e a documentação são seguros.

Reunindo três fragmentos, conseguimos reconstituir o fundo de um grande vaso romano de vidro negro como laca, pouco transparente, fortemente oxidado, irisado de roxo. E' característicamente romano. Foi encontrado na Gividade, há tempos. E' grosso, com expressura desigual e bastante primitivo quanto ao fabrico e fundição dos silicatos. Largura: $12 \mathrm{~cm}$; comprimento: $15 \mathrm{~cm}$. A parte posterior era achatada, o fundo encovado e as faces abauladas. E' pena este exemplar exibir-se tão incompleto. Mesmo assim constituiu um valioso e raro espécime de vidro romano de Brácara Augusta, que atribuímos ao século i por certas razões que agora não podemos explanar.

Outro exemplar é constituído por um fundo de copo de vidro branco, irisado de verde e roxo, oxidado, bastante manchado e gasto. Diâmetro: $7 \mathrm{~cm}$.

A grossura é desigual e variável, o que revela primitivismo de fabrico. A transparência é bastante perfeita.

Doutro copo depararam-se-nos dois pequeninos fragmentos com ornamentos, belamente expressivos nas suas linhas desigualmente quebradas, a toda a volta do bordo, na parte suprior. De alto abaixo apresenta traços e pontos marcados a água. O vidro é branco, pouco transparente, muito oxidado e belamente irisado de cores lindas provenientes da oxidação e patina da antiguidade. Pela sua perfeição de fabrico deve ser, dos séculos $n$ ou ui depois de Cristo.

Um pequeno frasco de vidro branco, transparente, ligeiramente oxidado, de grossura desigual, de que só apareceu a metade interior octogonal, apresenta no fundo a palavra latina FIDELIS em carcateres do século i. 
O mais artístico vaso romano descoberto em Brácara Augusta mas todo fragmentado, apresenta a forma de dedos em palma de mão, separados por séries de pontos borbulhados. A cor é branca, mas o fabrico é imperfeito quanto à cozedura.

Assemelha-se pela forma a outro vaso descoberto nas ruínas da Gitânia de Briteiros há anos, por Martins Sarmento, em vidro verde-claro e com nervuras externas.

O vidro colorido raramente apareceu em Brácara Augusta. Só raros fragmentos de vidro cor de vinho, de verde-azul e bastante de verde claro, se descobriram.

Quanto à grossura, predomina o vidro denso próprio de recipientes de líquidos, de cor escura, quase negra e de escassa transparência.

Exumou-se um pequeno fragmento escuro, com a largura de 1 centímetro, grossíssimo como se deduz.

A indústria vidreira romana penetrou na Gália nos meados do século i, mas já antes ali se fabricavam contas de colar e braceletes.

Dos vidros romanos descritos, alguns seriam de fabrico local bracarense, e outros de importação gaulesa e itálica.

$\mathrm{Na}$ Citânia de Briteiros foram descobertos muitos framentos vítreos de várias cores. Ali «foi possível reconstituir, quase completa, uma formosa taça de tom verde-claro (...) com nervuras exteriores, de um modelo frequente noutros meios lusitano-romanos...» (Mário Cardoso, Citânia de Briteiros e castro de Sabroso, Guimarães, 1956, p. 53).

Por este nosso artigo e por esta citação se antevê que nos séculos i e II, no termo de Brácara Augusta, estava em uso o vidro de várias cores. Utilizava-se no fabrico de vasos, de contas de colar, de taças com nervuras exteriores e de copos ornamentais.

\section{A. Ambrosio de Pina S. J.}

Diário do Minho, 23-9-1968

\section{Campanha Arqueológica da Falperra-1969}

Quem subir a estrada da Falperra e lançar os olhos para a esquerda dá logo de caras com o ponto mais alto da serrania - 600 metros acima do nível do mar e uns trinta e cinco aproximadamente mais elevado que o Sameiro, conhecido pelo monte das Cortiças, cuja plataforma superior assenta de quase todos os lados numa penedia ciclópica que se aprestava a ser utilizada pelos indígenas de antanho como suporte da muralha defensiva de um povoado castrejo.

Logo à vista ressalta uma ermida branca, a capelinha de Santa Marta, do see. xvi, mandada edificar pelo arcebispo D. Diogo de Sousa, utilizando 
materiais mais antigos e sobre outro santuário que podia remontra aos primeiros dias da cristandade da Península ou possivelmente mais velhos no qual se deu, como era uso após a conversão das comunidades, se fez a substituição da divindade pagã por um santo advogado das mesmas necessidades ou credor das virtudes semilares às que se atribuíam à divindade local. No caso devia ser qualquer deusa da fecundidade, muito querida das lactantes. Do lado nascente - a capela, sem fugir às normas dadas aos velhos construtores, para ali está orientada - foram incrustados na parede, sem critério algum (uma das pedras está deitada) e com finalidade para nós desconhecida, dois cachorros do primitivo romântico.

A festa de Santa Marta das Cortiças ou Santa Marta Velha - em oposição à Santa Marta o Leão cuja ermida está mais abaixo, para nascente realiza-se no dia 29 de Julho.

A noroeste foi erguido, aí há uns vinte anos — diz-nos o tio José Costa - o obelisco dedicado à Senhora da Assunção, obra de que o impulsionador, segundo nos disseram, foi um tal padre Guilherme, pároco de Esporões, e já falecido, com um facto curióse que logo apontaremos.

A partir do cimo encontram-se os vestígios de uma povoação luso-romana que tem sido campo de algumas escavações arqueológicas realizadas nos últimos anos. Paredes, bases de colunas, frgamentos de cerâmica comum, tégulas. De tudo isso falam os relatórios.

As moedas são na maioria do tempo de Constantino e algumas de Constâncio Cloro. Isto faz-nos relacionar o castro com alguns circunvizinhos. Da Citânia (Briteiros) falava-nos ontem a Senhora Maria Carpinteira, de Esporões que trabalha nesta exploração como jornaleira da Câmara.

Eram aliados os dois «povos». E os meios de comunicação eram tão facilitados que bastava a uns arrebolarem pelo ar um machado para os outros o receberem do outro lado!

Ora é neste local que desde o dia sete de agosto decorre uma campanha arqueológica na qual toma parte um grupo de estudantes.

Este Campo de férias é patrocinado pela Câmara Municipal e pela Junta Distrital de Braga.

\section{António de Matos Reis}

Diário do Minho, 23-8-1969

\section{A procura dos despojos venerandos da Bracara Augusta}

As escavações em curso na zona de Maximinos, mercê das quais acabam de ser encontradas as ruínas de um edifício da época romana, incluindo colunas, capitéis e outros elementos arquitectónicos, além de algumas moedas, fragmentos de cerâmica, de vidro, etc., foram visitadas pelo Sr. Dr. Jorge de Alarcão, director da estação arqueológica de Conimbriga, que considerou a parte já desobstruída, do maior interesse. 
No acto da visita, encontravam-se presentes os Srs. Dr. Viriíto Nunes, presidente da Cámara Municipal; Dr. Egídio Guimarães, vereador do pelouro da Cultura; Cónego Arlindo Ribeiro da Cunha, Dr. Rigaud de Sousa, Alberto Jorge de Matos, secretário da presidência da Câmara e vários alunos do Curso de Introdução à Arqueologia, alguns dos quais têm tomado parte activa nos trabalhos.

No decorrer da troca de impressões suscitada pelos resultados das pesquisas, foi apontada a necessidade da delimitação de uma zona de interesse público ou, mesmo, camarário, onde se realizem em maior escala trabalhos de sondagem, tendentes a trazer à superfície os despojos venerandos da Brácara Augusta.

Diário do Minho, 15-11-1969

\section{NOTAS}

1 - Uma sepultura de tijolo semelhante foi encontrada em Braga na Avenida da Liberdade, em 1966. Sobre outros achados nesta zona, ver VASCONCELos, 1918, p. 366. Quanto ao espólio, desconheço onde possa estar. Não voltámos a encontrar noticiário sobre este assunto, contrariamente ao que o jornal prometera; nem noutros jornais da mesma época. Ver ainda notícia 73.

3 - CIL 22425 e 2431. Actualmente guardam-se no museu D. Diogo de Sousa, em Braga. Ver texto 6.

4 - A rua de Trás da Sé correspondia à actual rua da Senhora do Leite.

Belino, 1900, p. 66, refere sepulturas, mas à frente da Sé.

5 - Desconheço o seu paradeiro. Deve porém referir-se que em local imediato (jardim do Solar das Carvalheiras), Albano Belino encontrou um miliário, não sabemos em que condições. Não nos admiraria que fosse o mesmo, uma vez que o possuidor daquele solar, Jerónimo da Cunha Pimentel, era um homem muito culto que, entre outras, participou na Conferência Citaniense de 1877 e no Congresso Internacional de Antropologia e Arqueologia Pre-histórica (Lisboa 1880).

6 - As duas lápides estudadas são as CIL 22425 e 2431 . Actualmente guardam-se no Museu D. Diogo de Sousa, em Braga. Ver texto 3.

7-Sobre o problema deste Museu ver Oliveira, 1983 e textos 8-12.

13 - Desconheço qualquer outro pormenor sobre este achado.

14 - Desconheço qualquer outro pormenor sobre este achado.

16 - Desconheço qualquer outra referência a este achado. Dume érica de achados arqueológicos e foi sede de um importante bispado na Idade Média.

17 - desconheço qualquer outro pormenor sobre este achado. 
18 - Sobre este mosaico ver, entre outros, OLIVEIRA, 1978, p. 26, nota 19; VASCONCELOS, 1923-24, p. 164-65, com reprodução e Figueiredo, 1899, p. 179-80.

19 - Perdida. Para a sua bibliografia ver Sous A, 1973.

20 - Desconheço qualquer outra notícia referente a esta estátua. Desconheço também qualquer livro deste arcebispo. Procurei também em D. Rodrigo da Cunha, mas nada encontrei.

21 - Sobre descobertas neste local ver RELINo, 1895, VASCONCELos, 1918, p. 258 e Sous A-Ponte, 1970.

22 - Ver nota 21.

23 - A rua dos Sapateiros corresponde ao troço da rua D. Frei Caetano Brandão entre a rua da Sé e a rua D. Diogo de Sousa. Porque as notícias são confusas e mostram bem a mentalidade da época, transcrevemo-las todas.

27 - Sobre outros achados na ocasião destes trabalhos, ver apenas OLIVEIRA, 1978, p. 27-28.

28 - Sobre a acção da Câmara de Braga no domínio da arqueologia e seus esforços para a criação de um museu ver OliVeira, 1979 e Oliveira, 1983.

29 - Sobre o achado de u ma moeda de Honorio neste local ver Híólit o, 1961 , p. 18.

31 - Há a tradição da cidade de Braga estar minada por uma rede de subterrâneos. De concreto, porém, nada sabemos. Quanto a uma posterior intervenção da Câmara desconhecemos qualquer notícia.

33- -Ver BELIN O, 1895(1).

34- Ver Belino, 1896.

37 - Sobre Albano Belino ver, além das notícias aqui referidas, O Live IR A, 1979, p. 166.

38 - $\mathrm{O}$ arquitecto Ernesto Korrodi publicaria a primeira monografia sobre a capela de S. Frutuoso.

39 - Refere-se ao monte Redondo, Guisande, Braga. Sobre os trabalhos que aí desenvolveu, ver BELINo, 1909, p. 7-15 e 19-28 e textos seguintes.

41-Sobre esta deliberação ver O LIV E IR A, 1979, p. 179.

42 - Sobre estas escavações ver BELINo, 1909, p. 15-18. Sobre esta estação ver Sou S A, 1970.

46 - A colecção arqueológica de Albano Belino viria a ser, mercê da incúria da Câmara de Braga e dos cidadãos bracarenses, dispersa pelo Museu da Sociedade Martins Sarmento, Guimarães e Museu Nacional de Arqueologia, Lisboa. Pouco terá ficado em Braga. Ver Cardoso, 1972, TAgilde, 1907 e Aquisições do Museu Etnológico Português, «Arqueólogo Português», Lisboa, 13, 1908, p. 375; 16, 1911, p. 110, 116 e 122. Sobre a colecção ver SEVERo, 1903.

50 - O Visconde da Torre era cidadão bracarense. Desconheço qualquer outro pormenor sobre esta notícia. 
51 - Desconheço qual seria a lápide. BELino, 1905, estuda duas do mesmo local mas que me parece não serem as mesmas. Esta notícia já tinha sido dada em Olive IRA, 1969, p. 180.

53 - Actualmente no Museu da Sociedade Martins Sarmento, em Guimarães. Ver Belino 1895, p. 7 e Cardoso 1972, p. 49.

57 - Sobre o destino da colecção de Albano Belino ver texto 46 e nota.

60-Notícia já referida em Olive IRA, 1979, p. 180-81.

61 - Sobre o assunto ver OLIVE IRA, 1978, p. 25.

62 - Sobre o problema da criação do museu arqueológico ver OLIVEIRA, 1983.

64-Penso ser o mesmo local da notícia 61, isto é no largo de S. Paulo. Ver bibliografia na nota aquela notícia.

68 - O campo de Portas ficava a Este da actual Avenida Cidade do Porto. Ver Oliveira, 1978, p. 29 e mapa.

71 - Actualmente no Museu dos Biscaínhos, Braga.

72 - O museu, que seria o museu D. Diogo de Sousa, só viria a ser criado em 1918. Ver OliveIRA, 1983.

73 - A zona envolvente da igreja da Senhora-a-Branca é uma das mais desconhecidas da arqueologia bracarense. Os únicos achados que se conhecem são de natureza funerária. Ver texto 1 e respectiva nota.

75 - Pensamos ser a mesma pedra de armas estudada por Nó BREGA, 1970, p. 168-75 que se guarda no museu D. Diogo de Sousa, Braga. O café em obras naquela data era o café Viana.

78-Para uma localização desta quinta ver o mapa de Oliveira, 1978.

80 - Pelo seu insólito e pelo que poderá representar como elemento de conhecimento público da arqueologia bracarense, transcreve-se esta notícia bem como a seguinte.

82 - Sobre a problemática da criação deste museu ver O LIV E IRA, 1983.

86 - Desconheço qualquer outra notícia ou informação sobre este texto.

87 - Sobre este sarcófago, que se guarda no Tesouro da Sé de Braga, ver BARREIROS, 1933, 1951 e 1952 e FEIO, 1951 e 1953.

88 - É esta a primeira e única notícia até agora publicada sobre este grande castro. Segundo uma informação que nos foi dada, pessoalmente, pelo professor Carlos Teixeira, a exploração que efectuou neste povoado foi feita simultaneamente com a que fez no Monte Castro (ver notícia seguinte). Carlos Teixeira era, ao tempo, professor no liceu Sá de Miranda, Braga, e responsável pelo seu internato.

89 - Primeira notícia de certo vulto sobre este castro. Sobre ele ver Teixeira, 1936, CAs Tro, 1980 e nota à notícia 88.

90 - A rua Mártires da República é a actual rua D. Gonçalo Pereira. Segundo o senhor cónego Luciano Afonso dos Santos me informou, foi recolhido um bom pedaço deste mosaico no Tesouro da Sé de Braga que, porém, se desfez com o tempo. Ignoro se foi fotografado.

91 - Os objectos encontrados recolheram ao Museu D. Diogo de Sousa. Uma segunda notícia do provável troço de muralha seria dada em FEIO, 1956. 
92- As lucernas referidas são as estudadas por TEIXEIRA, 1938 e depois reestudadas por Sousa, 1966. A inscrição deve ler-se PINTA / MI.BO / / BOAE / NI.F.A.V., segundo Cortez, 1958. Deve referir-se que este autor localiza o seu aparecimento na Fonte do Idolo, o que está errado. Todos estes objectos estão guardados no Museu D. Diogo de Sousa, Braga.

93 - Noticia sobre o estado de abandono em que se encontra este monumento nacional, um dos mais singulares da arqueologia portuguesa, A imprensa voltaria a chamar, de quando em quando, a atenção para o seu lastimável estado de abandono.

95 - Os resultados destas escavações só foram parcialmente publicados por CUNHA, 1954 e 1954 (1). Ver ainda Cortez, 1954. O espolio paleolítico foi guardado no museu D. Diogo de Sousa e o do povoado da Santa Marta no Museu Pio XII, em Braga.

96 - Sobre este edificio ver PALOL, 1958.

97 - A sua zona de protecção foi dada em 27-12-1955. A classificação foi objecto de decreto-lei de 20-10-1945 e ainda dos decretos-lei 251/70, de 3-6-1970 e do 516/71, de 22-11-1971.

101 - Desconheço onde se encontram guardados estes vidros.

103 - Sobre este edificio ver Sousa, 1982.

\section{OUTRAS NOTÍCIAS}

Para além das notícias que acima republicamos, saíram ainda algumas mais que, por nada trazerem de novo ao conhecimento actual da arqueologia bracarense, não transcrevemos; damos, porém, a sua referência.

A notícia 1 nada acrescenta às já publicadas; as 2 e 3 transcrevem informações já dadas a conhecer com mais pormenor em Oliveira, 1979; as 4-12 terão apenas interesse para uma história da arqueologia em Braga; as 13-16 são mais algumas justas chamadas de atenção para o estado de abandono a que continua a ser votado o monumento romano denominado «Fonte do ídolo» (como aliás a notícia transcrita com o número 93); a 17 foi já publicada, em 1880, em Braga, e a número 18 viria também a sê-lo em 1900 (BELlino, 1900,1); as 19 e 20 nada trazem de novo ao que já era conhecido nas datas em que foram publicados; a 21 é 
um chorrilho pegado de asneiras; a 22 não se republica agora porque o já foi, na integra, em OLIVEIRA, 1983, as 23-25 são noticias de circunstância cujos títulos são bem explícitos sobre o seu conteúdo, sendo a 25 , igual à 24 ; a 26 não é mais que o questionário arqueológico que a Real Associação dos Arqueólogos Protugueses enviou para todas as câmaras municipais do país em 1881 e de que se conhece a resposta bracarense (CRUZ, 1980); e, finalmente, a 27 é um longo artigo que, para além de informações colhidas em Argote e D. Rodrigo da Cunha, refere as inscrições depois republicadas em CIL 24755 e SousA, 1973, 4.4 6-15 e 4.4 2-11 e dá uma informação ainda hoje desconhecida: «na obra de recolher a água das vertentes do chafariz da S. Tiago... foi encontrada, na profundidade de 10 palmos, uma larga rua de pedra e de argamassa de boa esquadria».

1 - Nos trabalhos arqueológicos realizados últimamente em Maximinos e em Santa Marta das Cortiças foram encontradas vestígios para a história antiga de Bracara Augusta, «Diário do Minho», 31-8-1966.

2-Câmara Municipal, «Comércio do Minho», 26-1-1897.

3 - Câmara de Braga, "Comércio do Minho», 6-6-1899.

4 - Curso de iniciação à arqueologia, "Correio do Minho», 13-1-1967

5 - Curso de iniciação à arqueologia, «Correio do Minho», 22-1-1969.

6 - Por terras da Lusitânia... O passeio de estudo dos alunos do curso de introdução à arqueologia, «Correio do Minho», 23-4-1969.

7 - C[arvalho], Afntónio] de — Curso de introdução à arqueologia. Ecos de um passeio de estudo, «Correio do Minho», 16-4-1970.

8 - Passeio de estudo do curso de introdução à arqueologia, «Diario do Minho», 18-4-1972.

9 - Curso de introdução à arqueologia, «Correio do Minho», 18-4-1972.

10 - Curso de introdução à arqueologia. Lição do sr. D. Domingos Pinho Brandão, «Correio do Minho», 21-2-1973.

11 - Curso de Arqueologia, «Correio do Minho», 19-10-1973.

12 - Beccmeçam as aulas do curso de arqueologia, «Diário do Minho», 19-10-1973.

13 - Fonte do ídolo, «Diário do Minho», 30-3-1945.

14 - Corte-ReAL, João Afonso - Monumento pré-histórico. O abandono da Fonte do ídolo em Braga, "Correio do Minho», 23-9-1950.

15 - Fonte do ídolo, «Diário do Minho», 3-9-1971. 
16 - Onde fica a Fonte do Idolo?..., «Diário do Minho», 8-2-1974.

17-Caldas, J. J. Pereira-Carta epigráphica ao auctor indefesso do Portugal Antigo e Moderno, "Comércio do Minho», 29-3-1879, 1-4-1879; 8-4-1879; 10-4-1879; 12-4-1879; 1-5-1879; 3-5-1879.

18-Archeologia, «Comércio do Minho», 11-8-1900.

19-Cadeia de Braga, «Comércio do Minho», 11-1-1903.

20 - Соецно, Constantino - Onde era a Braga romana, «Diário do Minho», 10-10-1925.

21 - Pina, A. Ambrosio de — Louça romana de Bracara Augusta, «Diário do Minho», 9-3-1970.

22 - Museu D. Diogo de Sousa, «Correio do Minho», 5-6-1973.

23 - No Semuiário Conciliar de Filosofia, após uma brilhante sessão solene em honra de S. Tomás de Aquino e de homenagem a Pio XII foi inaugurado o museu de arqueologia e arte sacra, "Correio do Minho», 27-4-1956.

24 - Associação dos Arqueólogos Portugueses. Foram postas em evidência as escavações levadas a efeito pela Câmara de Braga, "Correio do Minho», 30-1-1955.

25 - Associação dos Arqueólogos Portugueses, «Diário do Minho», 8-2-1955.

26 - Aliquis - Antigualhas de Braga. Qual teria sido a relação [de monumentosí] enviada [pela Câmara de Braga] há 82 anos?, «Diário do Minho», 2-2-1964.

27-Freitas, Bernardino de Sena - Excertos para a história de Braga. Fundação do Convento das Beligiosas da Conceição, «O Futuro», 3-7-1872. 


\section{ABREVIATURAS E BIBLIOGRAFIA}

B A R RE Iros, 1933 - Manuel Aguiar Barreiros - Um sarcófago romano cristão. Como apareceu, «Acção Católica», Braga, 18(1), Janeiro 1933, p. 27-28.

Barreiros, 1951-idem-Um sarcófago romana cristão do século $I V$, «Bracara Augusta», Braga, 2(17), Fevereiro 1951, p. 361-362.

Barreiros, 1952 - idem —* Ainda o sarcófago romano cristão da Sé de Braga, «Bracara Augusta», Braga, 4(22-24), Dezembro, 1952, p. 96-100.

Belino, 1895 - Albano Belino - Inscrições romanas de Braga (Inéditas), Braga, 1895.

B ELIN O, 1895(1) - idem - Inscrições e letreiros da cidade de Braga e de algumas freguesias rurais, Porto, 1895.

BELINO, 1896 -idem - Novas inscrições romanas de Braga (Inéditas), Braga, 1896.

BELIN O, 1900 - idem - Archeologia christã, Lisboa, 1900.

B ELIN O, 1900(1) — idem — Questionário archeológico, Braga, 1900.

Belino, 1905 -idem - Bracara Augusta, «Arqueólogo Português», Lisboa, 10, 1905, p. 118-119.

Belino, 1909 - idem - Cidades Mortas, «Arqueólogo Português», Lisboa, 14, 1909, p. 1-28.

Cardoso, 1935 - Mário Cardoso - Catálogo do Museu Martins Sarmento, Secção de epigrafia latina e escultura antiga, Guimarães, 1935.

Castro, 1980 - João Sampaio e Castro; Susana Correia; Eduardo Pires de Oliveira-O Castrum Maximum (Monte Castro) Braga. Arqueologia e História, in Actas do Seminário de Arqueologia do Noroeste Peninsular, vol. 2, Guimarães, 1980, p. 37-53.

Castroviejo, 1974 - Fernando Acuña Castroviejo - Mosaicos romanos da Hispânia Citerior. Ill Conventus Brucaraugustanus, «Studia Archeológica», Valladolid, 31, 1974.

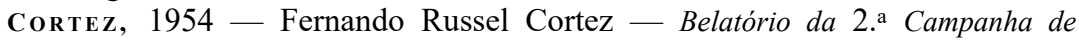
escavações arqueológicas mandadas efectuar pela Cámara Municipal de Braga, Braga, 1954 (dactilografado).

Cortez, 1958 - idem - Museu D. Diogo de Sousa. Boteiro Sumário, Braga, 1958.

Costa, 1941-Avelino de Jesus da Costa - Aos reverendíssimos párocos. Questionário arqueológico-histórico, «Acção Católica», Braga, 26(12), Dezembro 1941, p. 615-618.

Cruz, 1980 - Manuel Braga da Cruz - Braga no ano de 1882, «Bracara Augusta», Braga, 34(71), 1980, p. 705-710.

Conimhriga, 24 (1985), 5-83 
Cunha, 1954 - Arlindo Ribeiro da Cunha - No «oppidum» da Santa Marta, «Correio do Minho», Braga, 14-10-1954; 11-11-1954; 25-11-1955.

Cunha, 1954(1) —idem —Escavações no «oppidum» da Santa Marta, «Bracara Augusta», Braga, 5, 1954, p. 241-243.

Cunha, 1955 - idem - A cidade velha da Santa Marta, «Diário do Minho», Braga, 14-10-1955.

Excursion dans le nord du pays, Braga et Citdnia de Britciros. In Congres International d'Anthropologie et Archeologie Prehistorique. Compte rendu de la $9^{\mathrm{eme}}$ session a Lisbone 1880. Lisbon, 1884, p. 647-662.

Feıo, 1951 - Alberto Feio - Um sarcófago bizantino da Sé de Braga, «Bracara Augusta», Braga, 3(1), Junho 1951, p. 31-35.

Feıo, 1953 - idem - Mais duas palavras sobre o sarcófago bizantino da Sé de Braga, «Bracara Augusta», Braga, 4(4), Agosto 1953, p. 256-259.

Feio, 1956 - idem - Coisas memoráveis de Braga. II Origens da cidade. Braga romana, «Diário do Minho», Braga, 30-9-1956.

Figueiredo, 1889 - A. C. Borges de Figueiredo - Analecta archeológica.l. Braga, «Revista Archeológica», Lisboa, 3, 1889, p. 179-180.

Hı́ólito, 1961 -Mário de Castro Hipólito. Dos tesouros de moedas romanas em Portugal, «Conimbriga», Coimbra, 2-3, 1961, p. 1-166.

Mота Junior, 1895 - José Carlos Araujo de Mota Júnior - Os congressistas em Braga e Citánia em 1880, Braga ,1895.

Nobrega, 1971-Vaz Osório da Nóbrega - Pedras dt Armas e Armas Tumulares do Distrito de Braga, Vol. 1, tomo 2, Braga, 1971.

Nunes, 1980 - Henrique M. Barreto Nunes - Manuel Monteiro. Notas Bio-bibliográficas, Braga, 1980.

Oliveira, 1978 - Eduardo Pires de Oliveira - Os apontamentos arqueológicos de Braga de José Teixeira, «Minia», Braga, 2. a série, 1(1), 1978, p. 20-44.

Oliveira, 1979 - idem - A Câmara Municipal de Braga e a Arqueologia

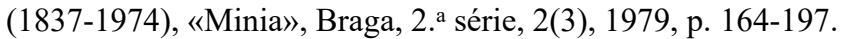

Oliveira, 1983 - idem e Maria Isabel Granja Fernandes - O Museu D. Diogo de Sousa (Braga), Braga, 1984 (no prelo).

Palol, 1958 - Pedro de Paiol - Arqueologia Cristiana de la España Bomana, Siglos IV-VI, Madrid, 1958.

Santos, 1973 - Luciano Afonso dos Santos - Breve Catálogo do Museu Pio XII (I - Seç̧ão Lapidar) in Falam Documentos, 2. a edição, Braga, 1973.

Severo, 1903 - Ricardo Severo - A colecção archeológica de Albano Belino em Braga, «Portugália», Porto, 1, 1903, p. 651-652.

Sousa, 1966 - J. J. Rigaud de Sousa - Inventário de Materiais para a Arqueologia Bracarense, «Bracara Augusta», Braga, 20(43-44), 1966, p. $165-178$.

Sousa, 1970 -idem - A estação arqueológica da Falperra. Notas para a sua história, «Arquivo de Beja», Beja, 25-27, 1970, p. 57-64. 
Sousa, 1973 - idem - Subsidios para a carta arqueológica di Braga, «Studia Arqueológica», Santiago de Compostela, 23, 1973.

Sousá, 1982 - Idem e Eduardo Pires de Oliveira- Subsidios para o estudo das olarias de Bracara Augusta. "Trabalhos de Antropologia e Etnologia»; Porto, 24(2), 1982,p. 359-69

Sousa-Ponte, 1970 - idem e Maria La Sálete da Ponte - Novos elementos para a arqueologia bracarsnse in Actas das I Jornadas Arqueológicas, vol. 2, Lisboa, 1970, p. 389-411.

TAgilde, 1907 —Abade de Tagilde - O Museu Archeológico — «Revista de Guimarães», Guimarães, 24, 1907, p. 79-81.

TEIXE IR A, 1936 - Carlos Teixeira - Subsídios para a arqueologia bracórense. I O Monte Castre (Castrum Maximum), «Anais da Faculdade de Ciências», Porto, 21, 1936. Republicado em «Rracara Augusta», Braga, 6-7 (31-34), 1955-56.

TEIXEIRA, 1938 - idem - Subsidios para o estudo da arqueologia bracarense.

II Lucernas, «Trabalhos da Sociedade Portuguesa de Antropologia e Etnologia», Porto, 8(3-4), 1938.

Vasconcelos, 1902 - José Leite de Vasconcelos - Notícias Várias, «Arqueólogo Portugués», Lisboa, 1902, p. 283-88.

Vasconcelos, 1918 - idem - Braga romana, «Arqueólogo Portugués», Lisboa, 23,1918 , p. 356-360.

Vasconcelos, 1923-4 - idem - Monumentos arqueológicos. 5 Mosaicos de Braga, «Arqueólogo Portugués», Lisboa, 26, 1923-24, p. 164-65. 